\title{
Evidence of recent changes in the ice regime of lakes in the Canadian High Arctic from spaceborne satellite observations
}

\author{
Cristina M. Surdu ${ }^{1}$, Claude R. Duguay ${ }^{2}$, and Diego Fernández Prieto ${ }^{1}$ \\ ${ }^{1}$ Earth Observation Science, Applications and Future Technologies Department, European Space Agency (ESA), \\ European Space Research Institute (ESRIN), Frascati (Rome), Italy \\ ${ }^{2}$ Department of Geography and Environmental Management and Interdisciplinary Centre on Climate Change, \\ University of Waterloo, Waterloo, Ontario, Canada
}

Correspondence to: Cristina M. Surdu (cristina.surdu@esa.int) and Claude R. Duguay (crduguay@uwaterloo.ca)

Received: 25 September 2015 - Published in The Cryosphere Discuss.: 17 November 2015

Revised: 24 March 2016 - Accepted: 17 April 2016 - Published: 10 May 2016

\begin{abstract}
Arctic lakes, through their ice cover phenology, are a key indicator of climatic changes that the high-latitude environment is experiencing. In the case of lakes in the Canadian Arctic Archipelago (CAA), many of which are ice covered more than 10 months per year, warmer temperatures could result in ice regime shifts. Within the dominant polardesert environment, small local warmer areas have been identified. These relatively small regions - polar oases - with longer growing seasons and greater biological productivity and diversity are secluded from the surrounding barren polar desert. The ice regimes of 11 lakes located in both polardesert and polar-oasis environments, with surface areas between 4 and $542 \mathrm{~km}^{2}$, many of unknown bathymetry, were documented. In order to investigate the response of ice cover of lakes in the CAA to climate conditions during recent years, a 15-year time series (1997-2011) of RADARSAT1/2 ScanSAR Wide Swath, ASAR Wide Swath, and Landsat acquisitions were analyzed. Results show that melt onset occurred earlier for all observed lakes. With the exception of Lower Murray Lake, all lakes experienced earlier summer ice minimum and water-clear-of-ice (WCI) dates, with greater changes being observed for polar-oasis lakes (9-24 days earlier WCI dates for lakes located in polar oases and 2-20 days earlier WCI dates for polar-desert lakes). Additionally, results suggest that some lakes may be transitioning from a perennial/multiyear to a seasonal ice regime, with only a few lakes maintaining a multiyear ice cover on occasional years. Aside Lake Hazen and Murray Lakes, which preserved their
\end{abstract}

ice cover during the summer of 2009 , no residual ice was observed on any of the other lakes from 2007 to 2011.

\section{Introduction}

In a rapidly changing climate (Zdanowicz et al., 2012; IPCC, 2013; Lenaerts et al., 2013; Woo and Young, 2014), with each of the last 3 decades being successively warmer than any preceding decade (Derksen et al., 2012) and as a result of complex energy exchanges between atmosphere, ocean, and land, the Arctic cryosphere is possibly transitioning towards a new state. As a major feature of the Arctic landscape, lakes, through their ice cover phenology (timing of ice formation, onset of melt, and end of break-up), are a key indicator of climatic changes (Heron and Woo, 1994; Duguay et al., 2006; Williamson et al., 2008) that the high-latitude environment is experiencing. Lake ice phenology is dependent on several factors, including meteorological conditions (e.g., air temperature, lack or presence of snow, snow depth and density, wind speed) and lakes' physical characteristics (e.g., surface area, bathymetry, elevation). However, long-term analysis indicates that lake ice phenology is primarily responsive to air temperature (Palecki and Barry, 1986; Jeffries et al., 1996; Duguay et al., 2006). Increasing air temperatures in the Canadian Arctic in all seasons, with an almost total absence of negative temperature anomalies over the past 4 decades, has altered the ice regimes of many Arctic lakes (e.g., timing of ice formation and decay, maximum ice thickness), with later 
freeze-up and earlier break-up dates for lakes in this region (Derksen at al., 2012).

The lake ice season starts with ice formation on the lake surface or freeze onset, which is the first day of the year on which the presence of ice is detected in a pixel. As the ice season progresses, a solid ice cover forms and the lake becomes completely frozen over. In spring, lake ice melt onset (MO) is considered as the first day of the year on which melt is detected in a pixel, observed as ice-free patch(es) on the otherwise ice-covered lake surface and marks the beginning of the break-up season. Gradually, more ice starts to melt until the lake becomes ice free or water clear of ice (WCI). The first day with no ice on the lake surface is considered the end of the break-up season. Consequently, the break-up season extends from MO to WCI. The minimum lake ice cover extent prior to complete melt at the end of summer, also referred to as the summer ice minimum, is generally observed to occur a few days before the lakes become ice free or, in the case of lakes that maintain a multiyear ice cover on occasional years, a few days prior to ice refreezing in the fall. Changes in the ice phenology (i.e., timing of ice-on and ice-off dates) of Arctic lakes have major implications for the physical and biogeochemical processes and the aquatic primary production and fauna, as they are strongly dependent on the presence of ice (Smol and Douglas, 2007; Veillette et al., 2010; Michelutti et al., 2013). Recent studies of Arctic lakes indicate thinner ice covers and less lakes freezing to bed on the North Slope of Alaska during the winter (Surdu et al., 2014) and reduced summer ice cover, leading to the loss of perennial ice of lakes on Northern Ellesmere Island, Nunavut (Mueller et al., 2009), with a rapid decline observed since 2008, following persistent warm summer temperatures (Paquette et al., 2015).

The Canadian Arctic Archipelago (CAA), the study area of this investigation, extends approximately between 60$83^{\circ} \mathrm{N}$ and $60-123^{\circ} \mathrm{W}$, from the Low Arctic to the High Arctic, and covers a territory of approximately $1425000 \mathrm{~km}^{2}$, including over 35000 islands. This region is projected to experience the greatest annual temperature increase in the North American Arctic during the course of the next 8 decades (ACIA, 2005). Projected climate conditions (20412070) employing two similar Canadian Regional Climate Model (CRCM) scenarios (Brown and Duguay, 2011) show that, consequent to loss of perennial ice, lakes on Ellesmere Island will experience maximum ice regime changes (e.g., shorter ice cover duration, thinner ice covers, loss of perennial/multiyear ice). As a result, lakes are projected to breakup earlier by over 30 days, with lakes in the CAA being expected to experience shorter ice seasons by $25-40$ days. It is hypothesized that lakes located in polar-oasis environments across the CAA may experience greater changes than those within the areas with typical polar-desert climate.

Polar or High Arctic oases are fairly small regions (with surface areas ranging from $10^{-2}$ to $10^{2} \mathrm{~km}^{2}$ ) (Woo and Young, 1997) of relatively great biological production and di- versity, with warmer soil and longer growing season (Courtin and Labine, 1977), discretely localized from the surrounding arid landscape of polar deserts (Svoboda and Freedman, 1981). Polar oases cover $6 \%$ of the High Arctic landscape (Bliss, 1977). Several polar oases have been identified across the High Arctic and, in general, these oases are located in shrub zones (Edlund and Alt, 1989) or in sedge meadows and polar semi-desert areas (Bliss, 1977). Polar oases can be separated into thermal and biological oases. Thermal polar oases have an atypical warmer microclimate than the surrounding polar desert (i.e., the vicinity of Lake Hazen, including Craig Lake, Buchanan Lake near Eureka, and several areas on Devon Island). Unlike polar thermal oases, the biological oases have a climate similar to polar deserts but are characterized by increased biological productivity and diversity. Polar Bear Pass, a wetland considered to be a critical area for migratory birds, caribou, and muskox (Young and Labine, 2010), is a typical polar biological oasis.

Monitoring changes in the lake ice cover and the rate at which they occur in the High Arctic is limited by the sparse and inconsistent observations and the short observational period in these remote regions. Accurate and consistent monitoring of small Arctic lakes requires a complex combination of spaceborne observations, model simulations, and where available, in situ measurements. Opportunities exist to monitor small lakes across the Arctic by exploiting the existing observations from heritage C-band synthetic aperture radar (SAR) missions (i.e., ERS-1/2, ENVISAT's Advanced Synthetic Aperture Radar (ASAR), RADARSAT-1/2, and Sentinel-1A). These missions, complemented by data from optical sensors (i.e., Landsat), improve detection of ice cover conditions of Arctic lakes.

Previous knowledge about past ice conditions for small High Arctic lakes is limited to a few lakes located on Northern Ellesmere Island (Belzile et al., 2001; Jeffries et al., 2005; Mueller et al., 2009; Cook and Bradley, 2010) and Colour Lake located on Axel Heiberg Island (Adams et al., 1989; Doran et al., 1996). Latifovic and Pouliot (2007) have provided records of ice conditions for larger High Arctic lakes, results obtained from the Advanced Very High Resolution Radiometer (AVHRR), at $1.1 \mathrm{~km} \times 1.1 \mathrm{~km}$ spatial resolution. Lakes that have been previously studied and are also analyzed in the current study include Upper and Lower Murray Lakes, previously monitored between 1997 and 2007 (Cook and Bradley, 2010), Lake Hazen, and Stanwell Fletcher Lake between 1985 and 2004 (Latifovic and Pouliot, 2007). However, changes that lakes have undergone over the last 2 decades and the current state of ice conditions for most High Arctic lakes remain unknown.

In order to identify possible ice regime changes for 11 lakes in the central and eastern Canadian High Arctic from 1997 to 2011 using available SAR and optical spaceborne satellite observations, the main objectives of this study are (1) to analyze and report the annual rate of change in the timing of ice decay onset, summer ice minimum, and end of 
ice break-up; (2) to comparatively investigate the changes in the ice regimes of polar-desert lakes versus those of polaroasis lakes; and (3) to continue observation records of some lakes that have been previously studied and to set the baseline data of a long-term monitoring record for High Arctic lakes. Additionally, this work aims to relate changes in the ice regimes of coastal High Arctic lakes to ongoing changes within other components of the cryosphere.

\section{Study area}

The High Arctic is in its majority a polar-desert area with mostly barren land surfaces, intense and persistent coldness, and low amounts of precipitation (Woo and Young, 2006). Mean annual temperature (1950-2011) at Alert, Nunavut $\left(82^{\circ} 30^{\prime} \mathrm{N}, 62^{\circ} 20^{\prime} \mathrm{W}\right)$, Canada, is $-19^{\circ} \mathrm{C}$; at Eureka, Nunavut $\left(79^{\circ} 59^{\prime} \mathrm{N}, 85^{\circ} 56^{\prime} \mathrm{W}\right)$, is $-18^{\circ} \mathrm{C}$; and at Resolute, Nunavut $\left(74^{\circ} 41^{\prime} \mathrm{N}, 94^{\circ} 49^{\prime} \mathrm{W}\right)$, is $-15^{\circ} \mathrm{C}$. For the same period, mean total precipitation is $146 \mathrm{~mm}(16 \mathrm{~mm}$ rain and $130 \mathrm{~mm}$ snow) at Alert, $67 \mathrm{~mm}(23 \mathrm{~mm}$ rain and $44 \mathrm{~mm}$ snow) at Eureka, and $128 \mathrm{~mm}$ (47 mm rain and $81 \mathrm{~mm}$ snow) at Resolute (Environment Canada, 2011).

Positive temperatures are registered only during July and August and occasionally in June and September, and most precipitation falls between July and October, typically as snow (Environment Canada, 2011). The summer melt periods are shortest $(\sim 3$ weeks) for the northern coast, while they last $\sim 8$ weeks near Alert and $\sim 10$ weeks at Lake Hazen (Keatley et al., 2007). This study indicates that melt periods of lakes on Northern Ellesmere Island last $\sim 6$ weeks, melt periods of Lake Hazen last $\sim 6.6$ weeks, while all other lakes have melt periods lasting $\sim 4$ weeks.

The current study focuses on 11 lakes mainly located in the central and eastern Canadian High Arctic, mostly small lakes with surface areas between 4 and $16 \mathrm{~km}^{2}$, with the exception of lake L11 on Baffin Island $\left(64 \mathrm{~km}^{2}\right)$, Stanwell Fletcher Lake $\left(339 \mathrm{~km}^{2}\right)$, and Lake Hazen $\left(542 \mathrm{~km}^{2}\right)$ - the largest lake within the Arctic Circle (Fig. 1). Selection of lakes considered three main aspects: (1) lakes had to be large enough so that break-up can be captured with SAR; (2) lakes had to be located in both arid (polar desert) and semi-desert (polar oasis) environments and thus allow a comparison between the two; and (3) lakes with previous ice records were selected in order to ensure continuity of observations. Six of the investigated lakes are located in polar-desert environments. For the purpose of assigning the lakes to a specific polar environment, the other five lakes have been categorized as polar-oasis lakes, with the note that unlike the thermal-oasis climate around Lake Hazen, Craig Lake, Buchanan Lake, and L4 on Devon Island, Hunting Camp Lake on Bathurst Island is a biological oasis with typical polar-desert climate.

A summary of each lake's basic characteristics is shown in Table 1. Maximum ice thickness of lakes on Northern Ellesmere at the beginning of winter ranges from 1.1 to $2 \mathrm{~m}$

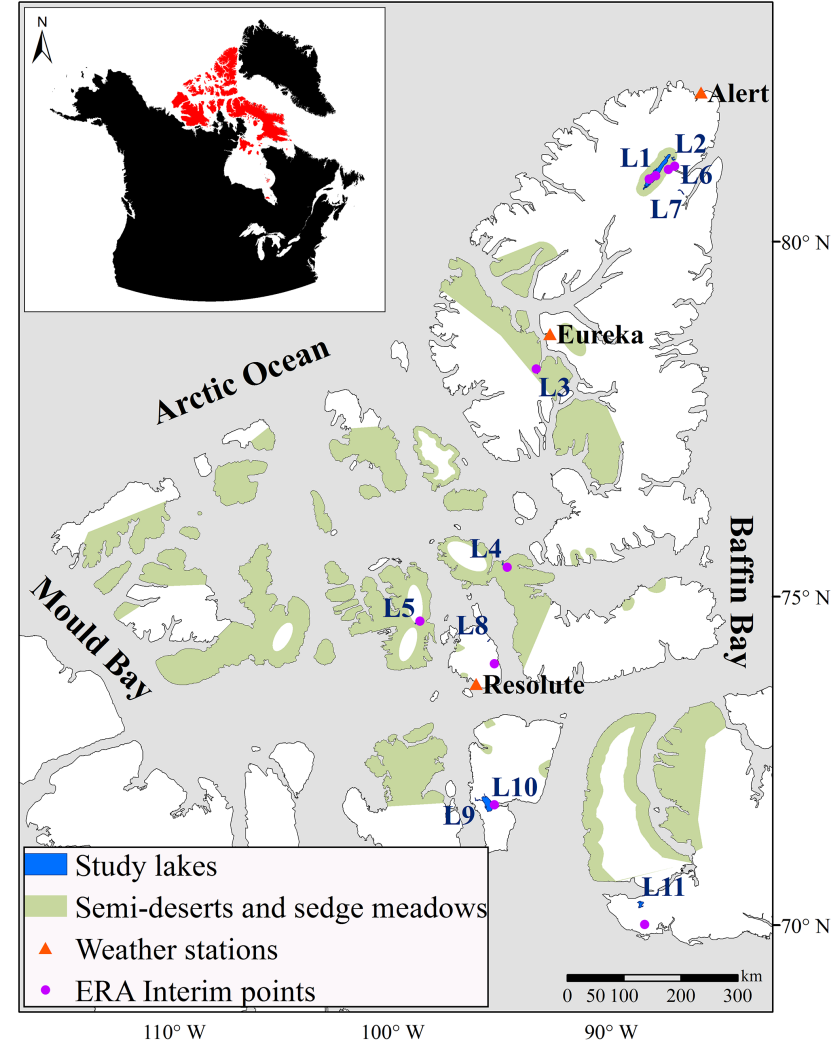

Figure 1. Location of monitored lakes in the Canadian Arctic Archipelago. Distribution of polar semi-deserts and sedge meadows is also shown (Woo and Young, 1997, after Bliss, 1977). Inset shows location of the Canadian Arctic Archipelago within the North American Arctic.

(Jeffries and Krouse, 1985; Belzile et al., 2001; Mueller et al., 2009). In situ observations on Upper and Lower Murray Lakes at the start of the melt season in early June 2005 indicated an ice thickness of 1.5-2.2 m (Cook and Bradley, 2010). Existing snow observations indicate average end-ofwinter snow depths of approximately $20 \mathrm{~cm}$ near Resolute Bay, Cornwallis Island, in 1976-1977 (Woo and Marsh, 1978), $26 \mathrm{~cm}$ on the plateau in Hot Weather Creek, Ellesmere Island, between 1989 and 1992 (Young et al., 1997), and less than $8 \mathrm{~cm}$ on the plateau of Polar Bear Pass, Bathurst Island, between 2008 and 2009 (Assini and Young, 2012). However, in situ snow depth measurements across the Canadian High Arctic are sparse/unavailable and inconsistent.

Polar oases are characterized by a milder microclimate (Woo and Young, 1997) that is mainly attributed to higher incoming radiation, given the fact that most frequently they develop in relatively flat coastal lowlands and are being protected by topography, the exception being the thermal oasis surrounding Lake Hazen (France, 1993). Lake Hazen is situated in a trough. Lake Hazen is sheltered from the cold Arctic Ocean air by the Grant Land Mountains ( $>2000 \mathrm{~m}$ ) in the north and a plateau (400-900 m) in the south. Similar to the 
Table 1. Location and basic characteristics of study lakes.

\begin{tabular}{llcllccll}
\hline ID & Lake name & Lat. N & Long. W & Location (island) & $\begin{array}{c}\text { Surface } \\
\text { area } \\
\left(\mathrm{km}^{2}\right)\end{array}$ & $\begin{array}{l}\text { Max. } \\
\text { depth } \\
(\mathrm{m})\end{array}$ & $\begin{array}{l}\text { Environment } \\
\text { type }\end{array}$ & $\begin{array}{l}\text { Perennial ice } \\
(1997-2011)\end{array}$ \\
\hline 1 & Hazen & $81^{\circ} 47^{\prime}$ & $71^{\circ} 21^{\prime}$ & Ellesmere & 542 & 280 & Polar oasis & $2000,2004,2009$ \\
2 & Craig & $81^{\circ} 51^{\prime}$ & $68^{\circ} 50^{\prime}$ & Ellesmere & 15.89 & - & Polar oasis & no \\
3 & Buchanan & $79^{\circ} 27^{\prime}$ & $87^{\circ} 37^{\prime}$ & Axel Heiberg & 16.8 & - & Polar oasis & no \\
4 & Unnamed & $76^{\circ} 33^{\prime}$ & $92^{\circ} 32^{\prime}$ & Devon & 9.05 & - & Polar oasis & $1997,1999,2001,2003-2004,2006$ \\
5 & Hunting Camp & $75^{\circ} 42^{\prime}$ & $98^{\circ} 33^{\prime}$ & Bathurst (Polar Bear Pass) & 4.23 & - & Polar oasis & no \\
6 & Upper Murray & $81^{\circ} 23^{\prime}$ & $69^{\circ} 41^{\prime}$ & Ellesmere & 7.6 & 83 & Polar desert & 1999,2009 \\
7 & Lower Murray & $81^{\circ} 20^{\prime}$ & $69^{\circ} 33^{\prime}$ & Ellesmere & 5 & 46 & Polar desert & $1999,2002,2006,2009$ \\
8 & Eleanor & $75^{\circ} 22^{\prime}$ & $93^{\circ} 57^{\prime}$ & Cornwallis & 5.91 & 88 & Polar desert & no \\
9 & Unnamed & $72^{\circ} 50^{\prime}$ & $95^{\circ} 28^{\prime}$ & Somerset & 5.81 & - & Polar desert & 2004 \\
10 & Stanwell Fletcher & $72^{\circ} 46^{\prime}$ & $94^{\circ} 51^{\prime}$ & Somerset & 339.29 & - & Polar desert & $2001-2004$ \\
11 & Unnamed & $70^{\circ} 50^{\prime}$ & $87^{\circ} 45^{\prime}$ & Baffin & 64.23 & - & Polar desert & no \\
\hline
\end{tabular}

Lake Hazen basin, sheltered by the neighboring mountains, the polar oasis on Fosheim Peninsula on Ellesmere Island (approx. $80^{\circ} 08^{\prime} \mathrm{N}$ ) experiences a greater amount of solar radiation, particularly during the month of June. Consequently, snowmelt in the area often occurs about a month early (Woo and Young, 1996). Additionally, vegetation growth is favored as a result of extended thaw seasons (Edlund and Alt, 1989). The biological oasis on Polar Bear Pass $\left(75^{\circ} 40^{\prime} \mathrm{N}\right.$, $98^{\circ} 30^{\prime} \mathrm{W}$ ), covers an area of approximately $100 \mathrm{~km}^{2}$, extends from one end of the island to the other, has a typical polardesert climate, and is characterized by long winters and cool, moist summers. Within the area lie two large lakes, several small lakes and a multitude of small ponds (Woo and Young, 1996).

Ellesmere Island contains some of the largest polar oases in the Queen Elizabeth Islands of Arctic Canada, including Fosheim Peninsula, Tanquary Fiord, and Lake Hazen (Edlund and Alt 1989). Other High Arctic oases have been identified on Devon Island (Bliss, 1977), Alexandra Fiord on Ellesmere Island (Freedman et al., 1994), Polar Bear Pass (Bathurst Island), and at Sherard Bay on Melville Island (Aiken et al., 1999). Given that the current analysis is limited by the availability of low spatial resolution SAR imagery $(150 \mathrm{~m}$ for ASAR, and $100 \mathrm{~m}$ for RADARSAT-1/2), Lake Hazen, Craig Lake, Buchanan Lake, lake L4 on Devon Island, and Hunting Camp Lake (biological oasis with polardesert climate) on Bathurst Island were the only investigated lakes located in polar-oases environments.

\section{Data and methods}

\subsection{Satellite acquisitions}

The ability of spaceborne sensors to monitor and detect changes in the ice cover of high-latitude lakes has been previously demonstrated from both an optical (Latifovic and Pouliot, 2007; Arp et al., 2013) and a SAR approach (Mor- ris et al., 1995; Duguay et al., 2002; Surdu et al., 2014) or a combination of optical and SAR (Cook and Bradley, 2010).

Due to frequent revisits at high northern latitudes and their ability to acquire data during polar darkness and through cloud cover, spaceborne SAR sensors are suitable for monitoring changes in the ice cover of High Arctic lakes. In Cband $(\sim 5.3 \mathrm{GHz})$ SAR imagery, the high contrast between ice and open water, representing the amount of radar signal or backscatter $\left(\sigma^{\circ}\right)$ returned to the sensor, allows detection of the timing of summer ice minimum and WCI (Morris et al., 1995; Duguay et al., 2002; Geldsetzer et al., 2010). Robust determination of the timing of lake freeze-up using SAR is limited by the low $\sigma^{\circ}$ contrast between the open water and the newly formed floating ice (Cook and Bradley, 2010) and also because the C-band co-polarized backscatter from water is not only sensitive to wind speed but also to wind direction (Geldsetzer and Van Der Sanden, 2013). Additionally, backscatter intensity is also dependent on local radar incidence angle (Duguay et al., 2002, Surdu et al., 2015). Considering the limitations that freeze-up detection pose with SAR, particularly at $\mathrm{VV}$ polarizations and to a lesser degree for $\mathrm{HH}$-polarized images, this study focuses on monitoring the break-up period of High Arctic lakes in the central and eastern Canadian High Arctic. The relatively coarse spatial resolution of SAR images used in this study, limited MO detection, particularly for small lakes (Cook and Bradley, 2010). To minimize this constraint, Landsat data were also used to identify the small areas of open water, otherwise uncertain in SAR imagery.

Given that the current study includes 11 lakes that were monitored for a period of 15 years, the number of satellite observations employed in the analysis was considerable: $\sim 27000$ SAR acquisitions (RADARSAT-1/2 and ASAR) and over 2000 Landsat images, with a mean frequency of image acquisition ranging from 2 to 9 days (Table 2); $\sim 1600$ SAR images were segmented to derive ice/open-water fractions. 
The ASAR images were provided by the European Space Agency (ESA) as a Wide Swath Mode Medium Resolution Image (ASA_WSM_1P) product. The ASAR instrument, on board ESA's ENVISAT, uses the ScanSAR technique when in wide-swath mode (the same as RADARSAT-1/2), provides a spatial resolution adapted for regional monitoring (approx. $150 \mathrm{~m}$, with a pixel spacing of $75 \mathrm{~m}$ ). The combination of $\mathrm{HH}$ - and VV-polarized images was acquired at incidence angles ranging from 17 to $42^{\circ}$. The time lapse between repeat passes (or revisit time) of ENVISAT is 35 days. In order to increase the frequency of observations, data from different tracks, descending and ascending orbits, were used.

RADARSAT-1/2 data, with a spatial resolution of $100 \mathrm{~m}$ and a pixel spacing of $50 \mathrm{~m}, 2 \times 2$ block averaged to $100 \mathrm{~m}$ (obtained from the Canadian Ice Service), acquired at incidence angles of 19-49 (RADARSAT-1) and 20$46^{\circ}$ (RADARSAT-2), are a ScanSAR Wide mode product. The single-polarized (HH) RADARSAT-1 and single- and dual-polarized ( $\mathrm{HH}+\mathrm{HV})$ RADARSAT-1/2 images were acquired approximately every 2-3 days during the break-up season of each year of study.

In addition to SAR data, archived Landsat 4 Thematic Mapper (TM) and Landsat 7 Enhanced Thematic Mapper Plus (ETM+) imagery, with a spatial resolution of $30 \mathrm{~m}$, was also used. Because of the data gaps in the Landsat imagery from 1997 to 2003 and the limited number of images during spring melt after 2003 for some of the lakes included in this study, the Landsat images were not used for calculating ice/open-water fractions. Instead, the Landsat imagery was utilized to complement and evaluate the SAR observations and thus build a reliable record from the beginning to the end of the ice season during the 15 years of record.

\subsection{Image processing and analysis}

A total of $\sim 1600$ SAR images acquired from the beginning of the melt season until the water was clear of ice (WCI or break-up end or $100 \%$ ice free), or, in cases when multiyear ice was identified, until the beginning of freeze-up, were selected. The selected images were segmented using the most common clustering method, the unsupervised $K$-means classification algorithm. This algorithm has proved to be a suitable method to discriminate between ice and open water and thus monitor the lake ice break-up using SAR data (Sobiech and Dierking 2013). Keeping in mind the large number of images analyzed in this study, the $K$-means algorithm was preferred over a fixed threshold method as it is flexible to changing ice conditions (Sobiech and Dierking, 2013) during the melt season. The unsupervised $K$-means classification is an iterative process in which image intensity values are divided into " $k$ " classes or clusters. Throughout the 20 iterations performed for each segmentation, the $K$-means classification assigned each intensity value to the class with the nearest arithmetic mean (minimum-distance technique).

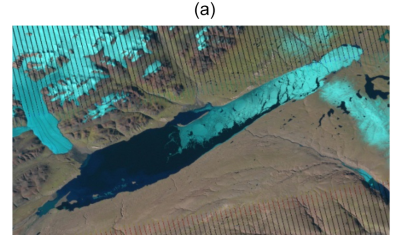

(c)

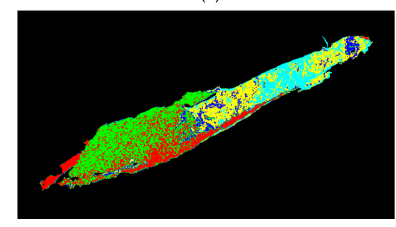

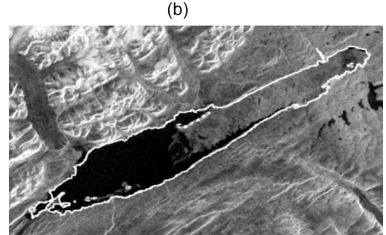

(d)

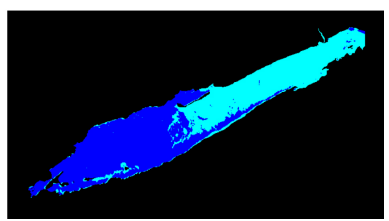

Figure 2. SAR-image segmentation processing steps: (a) Landsat image of Lake Hazen, 19 July 2010; (b) original ASAR image of Lake Hazen acquired on 19 July 2010; (c) $K$-means classified image (five clusters); (d) two-class map of ice (light blue) and open water (dark blue). The white line in the original SAR image represents the lake polygon that was used for defining the ROIs covering the lake.

In order to reduce the inherent speckle present in SAR images, a Lee filter (Lee, 1980) with a kernel size of $3 \times 3$ was applied to all geocoded images. After the speckle was removed, regions of interest (ROIs) covering the lake areas were selected. Following ROI designation (i.e., vector file of selected lake), image segmentation of each ROI was performed. The classification only included the pixels inside the ROI; all other pixels outside the lake boundaries were excluded from analysis. In order to account for the different ice classes, the segmentation was set to five clusters. To discriminate between ice and open-water clusters in the resulting segmentation maps, each segmentation output was visually assessed against the original SAR image. To additionally evaluate the class-merging accuracy, when available, segmentation results were assessed against optical images (Landsat) acquired on the same date. When ancillary optical data were not available, the backscatter threshold values of the original SAR acquisition were used to verify the segmentation results prior to cluster merging. Once clusters belonging to either the ice or open-water class have been identified, the resulting five classes were further merged into two classes: one ice and one open-water class in the ENvironment for Visualizing Images (ENVI) software, using the post-classification function. Following merging, a two-class map was generated for each segmented SAR image (Fig. 2). Text files showing the percentage $(\%)$ or fraction of open water and ice were extracted for each ROI of the classified maps in order to quantify the amount of ice present on lakes from the start of ice decay until the end of the break-up season.

In order to estimate the magnitude and significance of changes during the 15-year period, a Mann-Kendall test using Sen's slope (Sen, 1968) was performed. This nonparametric statistical test, widely used for detecting monotonic trends in hydrological long-term time series (Hirsch et 
al., 1982; Zhang et al., 2001), was deemed to be one of the most powerful trend tests (Hess et al., 2001) as it can deal with data that are not normally distributed and has minimum sensitivity to data gaps related to inhomogeneous time series (Tabari et al., 2011) or values below a detection limit. This method has been successfully used previously for detecting the presence of trends in long-term observation of river and lake ice (Smith, 2000; Futter, 2003; Duguay et al., 2006). However, caution should be used in interpretation of the statistical significance values considering that the trend analysis was performed on a relatively short-term time series of 15 years. The observed changes in ice regimes are shown as number of days, change being reported relative to the 19972011 calculated mean (days of change) for each individual lake observed from spaceborne acquisitions.

\subsection{Climate data}

Climate records of air temperature, including daily, monthly, and seasonal averages from 1997 to 2011, were collected in support of the analysis of satellite-derived ice phenology parameters. Given that the majority of weather stations in the CAA with longer climate records are situated at a significant distance from most lakes included in the current study, with distances ranging from 60 to $255 \mathrm{~km}$, a combination of weather station and surface air temperature reanalysis data was used to assess the observed changes in lake ice regimes. Additionally, Moderate Resolution Imaging Spectroradiometer (MODIS) thermal data were used to show differences in surface skin air temperature between warmer and colder years and thus capture the interannual temperature variability.

\subsubsection{Weather station records}

Meteorological station data from Environment Canada's National Climate Data and Information Archive were used for post-analysis of the spaceborne observations. These records include mean temperature data from 1 January 1997 to 31 December 2011, for three permanent weather stations: Alert, Eureka, and Resolute, Nunavut. Air temperature anomalies from 1997 to 2011 based on the available weather station annual mean temperature records are shown in Fig. 3. These anomalies are to be used as a reference in interpretation of lake ice events during the same period. The weather station records, complemented by ERA-Interim reanalysis data, were used for assessment of the relation between air temperature and ice phenology of lakes situated within a $0-120 \mathrm{~km}$ range from the weather station. Temperature records for lakes located further from the weather stations were based exclusively on ERA-Interim reanalysis data. Previous evaluations of ERA-Interim data over the Arctic shows that near-surface temperature estimates from reanalysis agree well with sparsely sampled observations from
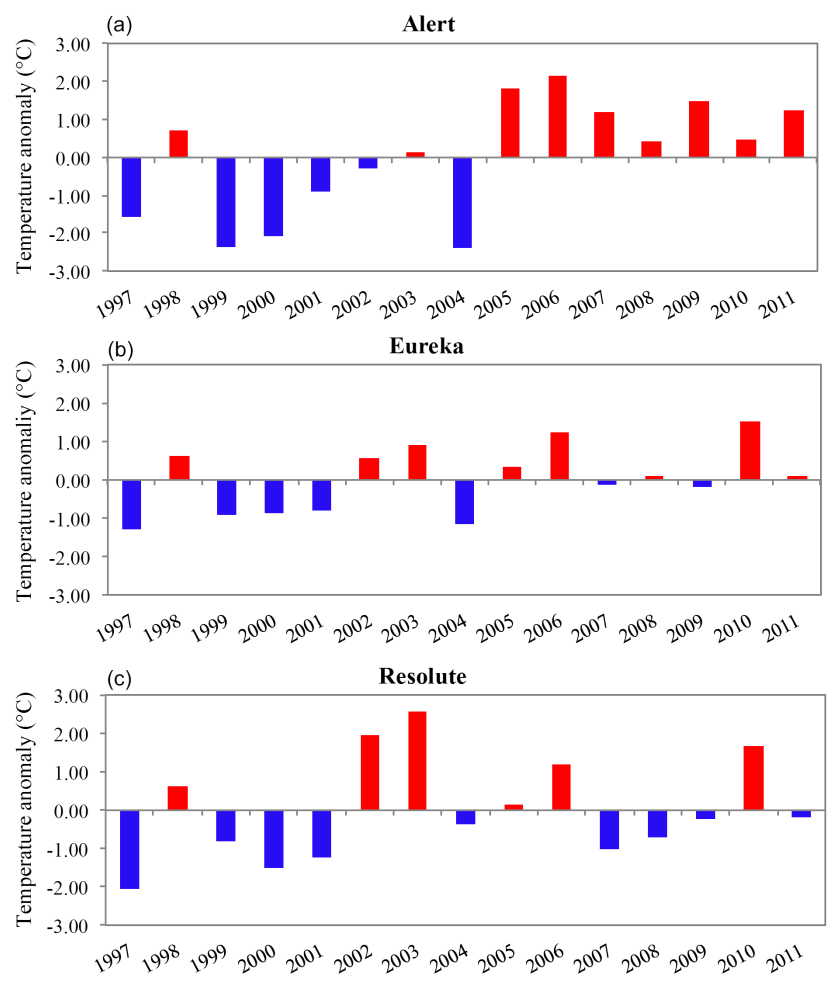

Figure 3. Air temperature anomalies for (a) Alert, (b) Eureka, and (c) Resolute relative to the 1997-2011 mean annual temperature.

conventional climatological data sets and are coherent across the Arctic (Simmons et al., 2010; Simmons and Poli, 2014).

\subsubsection{ERA-Interim reanalysis data}

The ERA-Interim is the largest global atmospheric reanalysis product of the European Centre for Medium-Range Weather Forecasts $\left(\right.$ ECMWF). The full-resolution $\left(\sim 0.75^{\circ} \times 0.75^{\circ}\right)$ gridded product is derived from data assimilation from a variety of sources: radiances from the Special Sensor Microwave Imager (SSM/I), radiosonde temperature, scatterometer ocean surface wind data including recalibrated data from the European Remote Sensing (ERS-1/2) satellites and, until 2009, from QuickSCAT (Dee et al., 2011). This reanalysis product provides global coverage since 1979. For the purpose of this study, the $2 \mathrm{~m}$ near-surface temperature computed with a sequential data assimilation scheme, advancing forward in time using 12-hourly analysis cycles, was utilized.

\subsubsection{MODIS surface temperature}

MODIS Aqua and Terra MOD 11-L2 data, at a spatial resolution of $1 \mathrm{~km}$, were used to derive the MODIS UW-L3 land surface temperature product (Kheyrollah Pour et al., 2014). In order to derive the monthly average land surface temperature (LST), daily averages were calculated first. For the daily- 
Table 2. Summary of yearly number and frequency of satellite images used for the ice cover monitoring of the investigated High Arctic lakes during the break-up season from 1997 to 2011.

\begin{tabular}{|c|c|c|c|c|c|c|c|c|c|c|c|}
\hline \multirow[t]{2}{*}{$\begin{array}{l}\text { Year of } \\
\text { observations }\end{array}$} & \multicolumn{11}{|c|}{$\begin{array}{c}\text { Total number of images used } \\
\text { (ASAR, RADARSAT-1/2, Landsat) }\end{array}$} \\
\hline & Hazen & Craig & Buchanan & $\begin{array}{c}\text { L6 } \\
\text { (Devon I.) }\end{array}$ & $\begin{array}{l}\text { Hunting } \\
\text { Camp }\end{array}$ & $\begin{array}{l}\text { Upper/ } \\
\text { Lower } \\
\text { Murray }\end{array}$ & Eleanor & $\begin{array}{c}\text { L9 } \\
\text { (Somerset I.) }\end{array}$ & $\begin{array}{l}\text { Stanwell } \\
\text { Fletcher }\end{array}$ & $\begin{array}{c}\text { L11 } \\
\text { (Baffin I.) }\end{array}$ & $\begin{array}{l}\text { Frequency } \\
\text { of image } \\
\text { acquisition } \\
\text { (days) }\end{array}$ \\
\hline 1997 & 10 & 9 & 97 & 74 & 58 & 9 & 53 & 42 & 35 & 80 & $4-13$ \\
\hline 1998 & 39 & 39 & 230 & 174 & 118 & 41 & 81 & 101 & 98 & 208 & $2-10$ \\
\hline 1999 & 30 & 34 & 227 & 198 & 126 & 30 & 98 & 113 & 11 & 187 & $3-11$ \\
\hline 2000 & 27 & 32 & 201 & 183 & 137 & 23 & 99 & 123 & 106 & 153 & $2-12$ \\
\hline 2001 & 41 & 50 & 436 & 435 & 307 & 38 & 251 & 301 & 278 & 298 & $2-7$ \\
\hline 2002 & 25 & 30 & 285 & 344 & 263 & 25 & 227 & 289 & 256 & 248 & $2-9$ \\
\hline 2003 & 13 & 13 & 265 & 340 & 272 & 16 & 220 & 265 & 241 & 259 & $2-10$ \\
\hline 2004 & 10 & 25 & 254 & 327 & 241 & 18 & 202 & 276 & 250 & 282 & $2-11$ \\
\hline 2005 & 23 & 21 & 250 & 326 & 272 & 31 & 212 & 267 & 233 & 258 & $1-11$ \\
\hline 2006 & 121 & 110 & 345 & 320 & 245 & 153 & 201 & 261 & 246 & 245 & $0-6$ \\
\hline 2007 & 131 & 124 & 328 & 351 & 294 & 152 & 225 & 284 & 259 & 285 & $0-6$ \\
\hline 2008 & 128 & 125 & 706 & 642 & 518 & 163 & 439 & 534 & 502 & 1243 & $0-5$ \\
\hline 2009 & 176 & 108 & 460 & 402 & 328 & 218 & 293 & 316 & 263 & 215 & $0-6$ \\
\hline 2010 & 170 & 52 & 321 & 298 & 236 & 181 & 189 & 183 & 142 & 332 & $0-7$ \\
\hline 2011 & 316 & 288 & 105 & 79 & 70 & 326 & 68 & 58 & 47 & 25 & $1-8$ \\
\hline Total/mean & 1260 & 1060 & 4510 & 4493 & 3485 & 1424 & 2858 & 3413 & 2967 & 4318 & $2-9$ \\
\hline
\end{tabular}

averaged UW-L3 product, observations are separated into either a daytime bin (from 06:00 to 18:00) or a nighttime bin (from 18:00 to 06:00 of the next day). For the geographical region of interest, two sets of data are produced, one containing the average of all daytime observations and the other containing those of all nighttime observations. Then, the intermediate sum of all MODIS Aqua/Terra daytime/nighttime observations for each pixel is calculated. These values are averaged together to produce the final monthly surface temperature average with equal weighting between daytime and nighttime values.

\section{Results}

Satellite observations of the ice cover on 11 lakes in the central and eastern Canadian High Arctic from 1997 to 2011 reveal great variability in the timing of ice $\mathrm{MO}$, summer ice minimum, and WCI dates, with a noticeable direction toward earlier ice-off dates and frequent loss of the multiyear ice cover. In light of the relatively short period of this study, the current results are indicative of a recent direction rather than a long-term trend observed in the ice phenology of the investigated High Arctic lakes. Additionally, these results could also be reflective of a recent cyclical behavior change of lake ice in response to changes in air temperatures during the 15year period of the study.

\subsection{Melt onset}

MO (start of break-up) was considered as the first date when surface melt or patches of open water were noticed in satellite observations through image segmentation for the SAR acquisitions and visual assessment of the Landsat images. At the start of the break-up season, pooling water was observed atop the ice cover of lakes on Ellesmere Island (Cook and Bradley, 2010). Considering the similar backscatter characteristics of pooling water on the ice surface and open water (Hall, 1998) at the beginning of lake ice break-up, discriminating between ice and open water in SAR images poses certain challenges. In order to improve the accuracy of MO detection, the Landsat imagery provided a valuable complement to the SAR observations. As such, during the few years with larger temporal gaps for the available SAR acquisitions, the complementary optical images reduced the data gaps to less than 5 days between spaceborne acquisitions, thus considerably reducing the uncertainty in estimation of the MO date. Spaceborne observations were available for most lakes during MO from 1997 to 2011 (Table 3). Table 3 displays the range of observed MO dates (shown as DOYs) during this period, the mean MO date for each lake calculated based on 1997-2011 mean derived from spaceborne observations, and the total days, representing the calculated earlier/later MO days using the Mann-Kendall statistical test, relative to the 1997-2011 mean.

During the 15-year period with available satellite acquisitions, advanced MO (compared to the 1997-2011 observation period mean) was observed for all 11 lakes, with ear- 
Table 3. Melt onset dates shown as day of the year (DOY) for the studied lakes from 1997 to 2011. Missing values (NA) indicate the lack of available satellite imagery. Total days for each individual lake refer to the total number of days change during the 1997-2011 period and are reported to the mean melt onset DOY of the same period. The statistical significance is indicated by the $\alpha$ values.

\begin{tabular}{|c|c|c|c|c|c|c|c|c|c|c|c|}
\hline $\begin{array}{l}\text { Year of } \\
\text { observations }\end{array}$ & Hazen & Craig & Buchanan & $\begin{array}{l}\text { Unnamed } \\
\text { (Devon) }\end{array}$ & $\begin{array}{c}\text { Hunting } \\
\text { Camp }\end{array}$ & $\begin{array}{l}\text { Upper } \\
\text { Murray }\end{array}$ & $\begin{array}{l}\text { Lower } \\
\text { Murray }\end{array}$ & Eleanor & $\begin{array}{l}\text { Unnamed } \\
\text { (Somerset) }\end{array}$ & $\begin{array}{l}\text { Stanwell } \\
\text { Fletcher }\end{array}$ & $\begin{array}{c}\text { Unnamed } \\
\text { (Baffin) }\end{array}$ \\
\hline 1997 & 205 & NA & 209 & 232 & 200 & 194 & 194 & 208 & 183 & 169 & 182 \\
\hline 1998 & 168 & 168 & 193 & 184 & 171 & 184 & 184 & 193 & 170 & 165 & 169 \\
\hline 1999 & 177 & 184 & 189 & 217 & 171 & 176 & 176 & 194 & 183 & 180 & 178 \\
\hline 2000 & 171 & 165 & 172 & 191 & 192 & 165 & 164 & 198 & 186 & 177 & 185 \\
\hline 2001 & 167 & 167 & 188 & 200 & 177 & 167 & 169 & 200 & 184 & 178 & 185 \\
\hline 2002 & 173 & 167 & 195 & 196 & 175 & NA & NA & 203 & 184 & 179 & 197 \\
\hline 2003 & NA & NA & 192 & 191 & 180 & 171 & 173 & 191 & 186 & 181 & 194 \\
\hline 2004 & 162 & 166 & 199 & 233 & 186 & 171 & 164 & 200 & 186 & 188 & 210 \\
\hline 2005 & 171 & 170 & 191 & 210 & 174 & 182 & 182 & 200 & 181 & 175 & 189 \\
\hline 2006 & 197 & 183 & 186 & 213 & 173 & 168 & 168 & 199 & 179 & 181 & 192 \\
\hline 2007 & 168 & 162 & 185 & 183 & 167 & 166 & 165 & 185 & 178 & 172 & 179 \\
\hline 2008 & 160 & 166 & 185 & 184 & 167 & 166 & 164 & 186 & 179 & 167 & 180 \\
\hline 2009 & 179 & 165 & 191 & 194 & 170 & 166 & 162 & 194 & 184 & 179 & 187 \\
\hline 2010 & 159 & 163 & 180 & 175 & 169 & 172 & 174 & 175 & 178 & 171 & 179 \\
\hline 2011 & 174 & 172 & 172 & 172 & 164 & NA & NA & 173 & 173 & 168 & 174 \\
\hline 1997-2011 mean & 174 & 169 & 188 & 198 & 176 & 173 & 172 & 193 & 181 & 175 & 185 \\
\hline 1997-2011 total days & -14 & -3 & -15 & -39 & -20 & -13 & -20 & -23 & -7 & -3 & -3 \\
\hline$\alpha$ & $>0.1$ & $>0.1$ & 0.05 & 0.05 & 0.01 & 0.1 & 0.05 & 0.05 & $>0.1$ & $>0.1$ & $>0.1$ \\
\hline
\end{tabular}

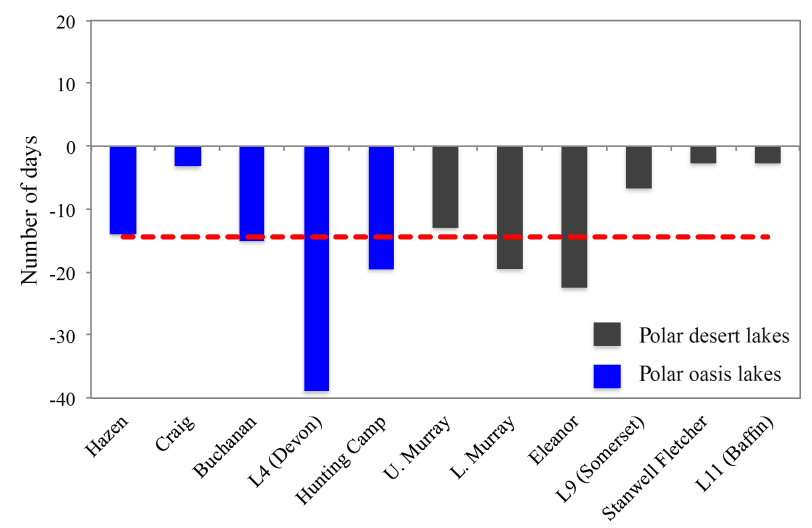

Figure 4. Changes - shown as number of days - in the melt onset date of investigated lakes in the central and eastern Canadian High Arctic (1997-2011). Number of days change is reported relative to the 1997-2011 mean melt onset day derived from spaceborne observations during this period. Lakes in polar-oasis environments are shown as blue bars and lakes in polar-desert environments are shown as grey bars. The red line indicates the 1997-2011 mean number of days change for melt onset.

lier MO by a total of 39 days for lake L4 on Devon Island ( $\alpha=0.05$ ), earlier by 20 days for Hunting Camp Lake (significant at the 0.01 level), by 15 days for Buchanan Lake at the 0.05 level, and by 3 days for Craig Lake, Stanwell Fletcher Lake, and lake L11 on Baffin Island $(\alpha=>0.1)$. Mean MO dates for lakes on Northern Ellesmere Island (i.e., Craig Lake, Upper and Lower Murray Lakes, and Lake Hazen) ranges between 18 June (DOY169) and 24 June (DOY175). MO for lake L4 on Devon Island, Eleanor Lake, and Buchanan Lake, was observed to start between 7 July (DOY188) and 17 July (DOY198). Overall, the greatest changes in timing of MO dates and statistical more significant - despite not being a long-term trend and rather a measure of change detection during a 15-year period - were observed for lakes located in polar-oasis (thermal and biological) environments (Fig. 4).

\subsection{Summer ice minimum}

The last date with a floating ice cover on the lake surface at the end of summer was considered the ice minimum date. During years when lakes maintained a multiyear ice cover, the summer ice minimum date was usually observed in late August to mid-September when melt concludes and most lakes start refreezing. The mean ice minimum date ranges from 12 July (DOY193, Craig Lake) to 25 August (DOY237, Stanwell Fletcher Lake). From 1997 to 2011, most lakes lost their summer ice cover during all years of investigation (Table 4). Table 4 displays the range of observed summer ice minimum dates (shown as DOYs) during this period, the mean summer ice minimum date for each lake calculated based on 1997-2011 mean (excluding the years when lakes maintained a partial summer ice cover) derived from spaceborne observations, and the total days, representing the calculated earlier/later summer ice minimum dates using the Mann-Kendall statistical test, relative to the 19972011 mean.

Generally, the lake ice cover was observed to melt earlier in the season during the years with positive annual air temperature anomalies and last longer into the summer during the years with negative annual air temperature anomalies. 
Table 4. Dates (shown as day of the year - DOY) when minimum ice cover was observed for the studied lakes from 1997 to 2011 . Missing values (NA) indicate the lack of available imagery. Total days for each individual lake refer to the total number of days change during the 1997-2011 period and are reported to the mean summer ice minimum DOY of the same period. The statistical significance is indicated by the $\alpha$ values.

\begin{tabular}{|c|c|c|c|c|c|c|c|c|c|c|c|}
\hline $\begin{array}{l}\text { Year of } \\
\text { observations }\end{array}$ & Hazen & Craig & Buchanan & $\begin{array}{l}\text { Unnamed } \\
\text { (Devon) }\end{array}$ & $\begin{array}{l}\text { Hunting } \\
\text { Camp }\end{array}$ & $\begin{array}{l}\text { Upper } \\
\text { Murray }\end{array}$ & $\begin{array}{l}\text { Lower } \\
\text { Murray }\end{array}$ & Eleanor & $\begin{array}{l}\text { Unnamed } \\
\text { (Somerset) }\end{array}$ & $\begin{array}{l}\text { Stanwell } \\
\text { Fletcher }\end{array}$ & $\begin{array}{c}\text { Unnamed } \\
\text { (Baffin) }\end{array}$ \\
\hline 1997 & 232 & 205 & 233 & 246 & 224 & 231 & 232 & 229 & 215 & 213 & 215 \\
\hline 1998 & 209 & 182 & 214 & 217 & 186 & 220 & 220 & 213 & 199 & 217 & 203 \\
\hline 1999 & 249 & 193 & 208 & 267 & 205 & 243 & 243 & 221 & 215 & 252 & 215 \\
\hline 2000 & 255 & 182 & 200 & 214 & 209 & 212 & 212 & 217 & 211 & 237 & 214 \\
\hline 2001 & 213 & 188 & 197 & 245 & 203 & 220 & 229 & 224 & 214 & 253 & 208 \\
\hline 2002 & 238 & 194 & 203 & 230 & 206 & NA & 241 & 227 & 224 & 257 & 218 \\
\hline 2003 & NA & 198 & 197 & 241 & 200 & NA & NA & 212 & 217 & 258 & 218 \\
\hline 2004 & 246 & 210 & 218 & 244 & 238 & 213 & 213 & 245 & 244 & 258 & 233 \\
\hline 2005 & 209 & 187 & 203 & 231 & 206 & 222 & 223 & 219 & 223 & 232 & 223 \\
\hline 2006 & 234 & 192 & 202 & 254 & 211 & 243 & 257 & 222 & 213 & 235 & 215 \\
\hline 2007 & 220 & 191 & 200 & 214 & 196 & 234 & 234 & 208 & 202 & 219 & 208 \\
\hline 2008 & 223 & 191 & 193 & 227 & 191 & 213 & 226 & 208 & 208 & 238 & 209 \\
\hline 2009 & 250 & 205 & 205 & 226 & 207 & 262 & 262 & 218 & 210 & 232 & 213 \\
\hline 2010 & 206 & 189 & 196 & 216 & 199 & 210 & 212 & 206 & 212 & 236 & 215 \\
\hline 2011 & 223 & 186 & 184 & 202 & 195 & 222 & 249 & 195 & 202 & 217 & 198 \\
\hline 1997-2011 mean & 229 & 193 & 204 & 232 & 205 & 227 & 232 & 218 & 214 & 237 & 214 \\
\hline 1997-2011 total days & -9 & -2 & -23 & -30 & -15 & 0 & 12 & -19 & -5 & -2 & -2 \\
\hline$\alpha$ & $>0.1$ & $>0.1$ & 0.05 & 0.1 & $>0.1$ & $>0.1$ & $>0.1$ & 0.05 & $>0.1$ & $>0.1$ & $>0.1$ \\
\hline
\end{tabular}

Similarly, the occasional multiyear ice on several lakes lasted from one year to the other during the years with negative annual air temperature anomalies. With the exception of the polar desert around Upper and Lower Murray Lakes that maintained relatively consistent ice conditions or a longer-lasting ice cover into the summer by 12 days $(\alpha=>0.1$, Lower Murray Lake) during the 15-year observation period, all other lakes experienced earlier minimum ice during the summer months and thus earlier ice-off dates. Lakes located in polaroasis environments experienced the earliest summer ice minimum dates, with lake L4 on Devon Island (30 days earlier, $\alpha=0.1$ ) and Buchanan Lake (23 days earlier, $\alpha=0.05$ ) experiencing the greatest change. Eleanor Lake, despite being a polar-desert type lake, experienced considerably earlier summer ice minimum dates ( 19 days earlier, $\alpha=0.05$ ). All typical polar-desert lakes experienced minimum negative change, with a lower statistical significance (2-5 days earlier, $\alpha=>0.1$ ) in the timing of the summer ice minimum date (Fig. 5).

Multiyear ice was observed on occasional years for Lake Hazen (2000, 2004, 2009), Upper Murray Lake (1999, 2009), Lower Murray Lake (1999, 2002, 2006, 2009), lake L4 on Devon Island (1997, 1999, 2001, 2003-2004, 2006), and Stanwell Fletcher Lake (2001-2004). Lakes formerly observed to maintain multiyear ice covers, such as Lake Hazen in the 1950s (Hattersley-Smith, 1974) and Stanwell Fletcher Lake in the early 1960s (Coakley and Rust, 1968), are shifting toward a more frequent seasonal ice cover. Similar to other High Arctic lakes that are rapidly transitioning from a perennial (persistence over decades or longer) or multiyear (persistence for $>1$ year) to a seasonal (annual melt

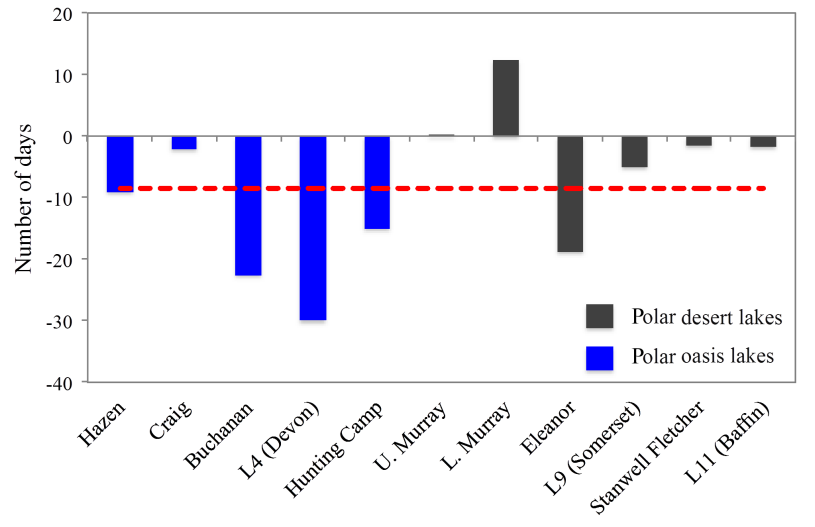

Figure 5. Changes - shown as number of days - in the summer ice minimum date of investigated lakes in the central and eastern Canadian High Arctic (1997-2011). Number of days change is reported relative to the 1997-2011 mean summer ice minimum day derived from spaceborne observations during this period. Lakes in polar-oasis environments are shown as blue bars and lakes in polardesert environments are shown as grey bars. The red line indicates the 1997-2011 mean number of days change for summer ice minimum.

out) ice cover (Paquette et al., 2015), lakes in the central and eastern Canadian High Arctic seem to experience a similar shift. From 1997 to 2011, L4 on Devon Island and Stanwell Fletcher Lake were the only lakes that preserved their ice cover for 2 or more consecutive years (i.e., 2003-2004 for L4 and 2001-2004 for Stanwell Fletcher Lake). 
Table 5. Water-clear-of-ice dates shown as day of the year (DOY) for the studied lakes from 1997 to 2011. Missing values (NA) indicate the lack of available imagery. Dash indicates that complete melt did not occur. Asterisks indicate the lakes that maintained an occasional perennial ice. Total days for each individual lake refer to the total number of days change during the 1997-2011 period and are reported to the mean water-clear-of-ice DOY of the same period. The statistical significance is indicated by the $\alpha$ values.

\begin{tabular}{|c|c|c|c|c|c|c|c|c|c|c|c|}
\hline $\begin{array}{l}\text { Year of } \\
\text { observations }\end{array}$ & Hazen* & Craig & Buchanan & $\begin{array}{l}\text { Unnamed } \\
\text { (Devon)* }\end{array}$ & $\begin{array}{c}\text { Hunting } \\
\text { Camp }\end{array}$ & $\begin{array}{c}\text { Upper } \\
\text { Murray* }\end{array}$ & $\begin{array}{c}\text { Lower } \\
\text { Murray* }\end{array}$ & Eleanor & $\begin{array}{c}\text { Unnamed } \\
\text { (Somerset)* }\end{array}$ & $\begin{array}{l}\text { Stanwell } \\
\text { Fletcher* }\end{array}$ & $\begin{array}{l}\text { Unnamed } \\
\text { (Baffin) }\end{array}$ \\
\hline 1997 & 233 & 208 & 234 & - & 225 & 232 & NA & 232 & 216 & 230 & 216 \\
\hline 1998 & 213 & 191 & 215 & 220 & 187 & 221 & 221 & 217 & 204 & 219 & 207 \\
\hline 1999 & 250 & 201 & 209 & - & 207 & - & - & 226 & 216 & 255 & 220 \\
\hline 2000 & - & 195 & 201 & 217 & 210 & 219 & 219 & 218 & 215 & 239 & 219 \\
\hline 2001 & 219 & 196 & 208 & - & 204 & 220 & 230 & 225 & 215 & - & 210 \\
\hline 2002 & 241 & 195 & 204 & 233 & 209 & 237 & - & 230 & 227 & - & 222 \\
\hline 2003 & $\mathrm{NA}$ & 199 & 198 & - & 202 & NA & NA & 214 & 219 & - & 220 \\
\hline 2004 & - & 210 & 219 & - & 244 & NA & NA & 248 & - & - & 234 \\
\hline 2005 & 210 & 188 & 204 & 233 & 207 & 223 & 230 & 220 & 224 & 237 & 224 \\
\hline 2006 & 235 & 194 & 203 & - & 212 & 249 & - & 225 & 215 & 236 & 217 \\
\hline 2007 & 221 & 200 & 201 & 217 & 197 & 237 & 241 & 210 & 203 & 222 & 209 \\
\hline 2008 & 224 & 195 & 194 & 228 & 195 & 219 & 228 & 214 & 209 & 246 & 210 \\
\hline 2009 & - & 209 & 206 & 227 & 208 & - & - & 219 & 212 & 234 & 215 \\
\hline 2010 & 210 & 192 & 197 & 217 & 200 & 211 & 217 & 207 & 213 & 237 & 219 \\
\hline 2011 & 225 & 192 & 185 & 204 & 197 & 224 & 251 & 196 & 203 & 223 & 199 \\
\hline 1997-2011 mean & 226 & 198 & 205 & 222 & 207 & 227 & 230 & 220 & 214 & 234 & 216 \\
\hline 1997-2011 total days & -9 & -4 & -24 & -8 & -15 & -2 & 13 & -20 & -5 & -4 & -5 \\
\hline$\alpha$ & $>0.1$ & $>0.1$ & 0.01 & $>0.1$ & $>0.1$ & $>0.1$ & $>0.1$ & 0.05 & $>0.1$ & $>0.1$ & $>0.1$ \\
\hline
\end{tabular}

\subsection{Water clear of ice}

The end of break-up was indicated by the absence of an ice cover over lakes ( $0 \%$ ice), also known as WCI. For years with sparse satellite imagery at the end of break-up, and thus with differences greater than 1 day between the date of minimum ice cover and the WCI date, the day when the lake became ice free was estimated by interpolating between the date of the last satellite image (either SAR or Landsat) that indicated the presence of ice on lake surface and the date of the next available satellite observation that showed $100 \%$ open water, based on the observed rate of ice decay from previous images.

The range of mean WCI dates for the observed lakes from 1997 to 2007 falls between 17 July (DOY198, Craig Lake) and 22 August (DOY234, Stanwell Fletcher Lake). The mean WCI date for Upper Murray and Lower Murray Lake is 15 August (DOY227) and 18 August (DOY230), respectively. Lakes remained completely ice free for several weeks prior to starting to refreeze, usually at the beginning of September when below-freezing air temperatures returned. While most lakes lost their ice cover every summer, observations indicate that a few lakes did not completely melt during the summer months (Table 5). Table 5 displays the range of observed WCI dates (shown as DOYs) during this period, the mean summer ice minimum date for each lake calculated based on 1997-2011 mean derived from spaceborne observations, and the total days, representing the calculated earlier/later WCI dates using the Mann-Kendall statistical test, relative to the 1997-2011 mean. Analysis indicates that the WCI date was generally earliest for polar- oasis lakes: Lake Buchanan (by 24 days, $\alpha=0.01$ ), Hunting Camp Lake (biological oasis) on Bathurst Island (by 15 days, $\alpha=0.1$ ), Lake Hazen (by 9 days, $\alpha=>0.1$ ), and lake L4 on Devon Island (by 8 days, $\alpha=>0.1$ ). WCI for the polardesert Eleanor Lake occurred earlier by 20 days $(\alpha=0.05)$. The polar-desert Lower Murray Lake experienced later WCI dates by 13 days ( $\alpha=>0.1$ ). Other than Lake Buchanan and Eleanor Lake that showed a significant statistical trend toward earlier open-water seasons, for all other lakes the significance level is greater than 0.1. Comparative changes in timing of the WCI date between lakes located in polar-desert environments and those in polar-oasis environments are shown in Fig. 6.

\section{Discussion}

\subsection{Changes in lake ice regimes 1997-2011}

\subsubsection{The break-up season}

For the majority of lakes, the break-up season (1997-2011) covered the months of June, July, and August, ice decay generally started in June and transitioned toward an ice-free lake cover until the second/third week of August. Depending on summer air temperatures and/or lake location and size, some lakes become ice free before the end of July. The analysis focused on the response of the lake ice cover to changes in air temperatures; however, other factors that contribute to lake ice break-up exist, including but not limited to on-ice snow depth and extent, wind action, and spring runoff. 


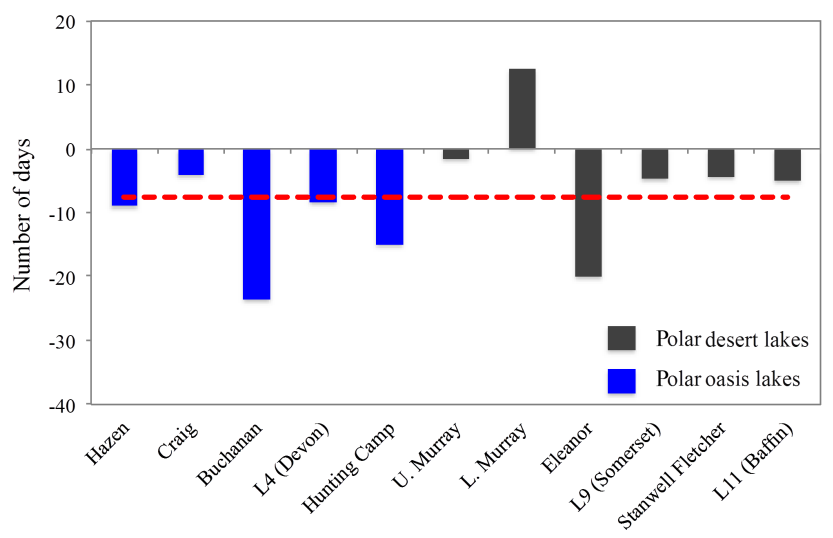

Figure 6. Changes - shown as number of days - in the water-clearof-ice date of investigated lakes in the central and eastern Canadian High Arctic (1997-2011). Number of days change is reported relative to the 1997-2011 mean water-clear-of-ice day derived from spaceborne observations during this period. Lakes in polar-oasis environments are shown as blue bars and lakes in polar-desert environments are shown as grey bars. The red line indicates the 1997-2011 mean number of days change for water that is clear of ice.

While interannual variability in the MO dates existed from 1997 to 2011, lakes generally experienced earlier MO during the years with positive air temperature anomalies and later MO during the years with negative air temperature anomalies. For instance, in 1997, a year with negative air temperature anomaly at Alert, NU, MO for Lake Hazen was observed on 24 July (DOY205), 31 days late compared to the 1997-2011 mean. MO for the same lake occurred by 15 days earlier (8 June, DOY159) in 2010, when the air temperature anomaly at Alert, NU, was positive. The large positive air temperature anomalies (e.g., 2005, 2006, 2007, 2009, and 2011) is at Alert a consequence of higher spring air temperatures during these years. Unusual warm years have been associated with anomalous high-pressure atmospheric events such as the one in the late winter of 1997/early spring of 1998, resulting in above-average temperatures over the Canadian Arctic (Atkinson et al., 2006). Furthermore, episodes of advection of moist, warmer air from the anomalous higher sea surface waters of the northwestern Atlantic in spring/early summer result in large positive anomalies in the near-surface temperature (Sharp et al., 2011).

Given the high albedo of snow, MO (the first appearance of open water) could be delayed if a layer of snow or snow ice formed during freeze-up is present on lakes at the beginning of the break-up season. Previous field observations revealed that the ice cover of Murray Lakes at the beginning of the 2005 break-up season entirely consisted of black ice, thus lacking the snow-ice layer (Cook and Bradley, 2010). Additionally, most of the high-latitude regions generally experience low amounts of snowfall $\left(<158 \mathrm{~mm}\right.$ year $\left.^{-1}\right)$. These facts could suggest that the presence of snow ice and/or snow on High Arctic lakes is not a significant driver of the break-
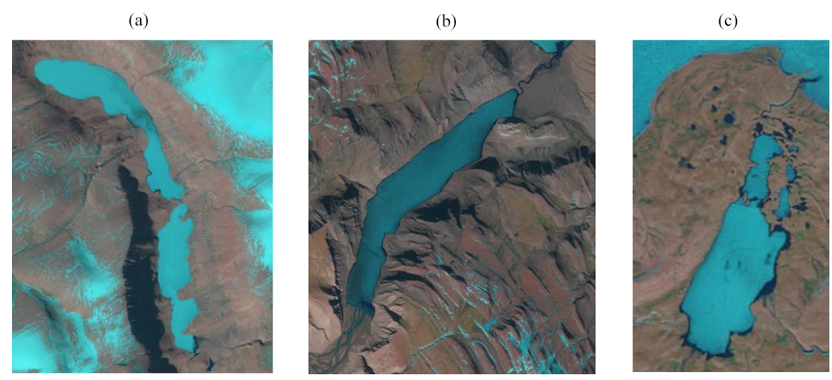

(d)

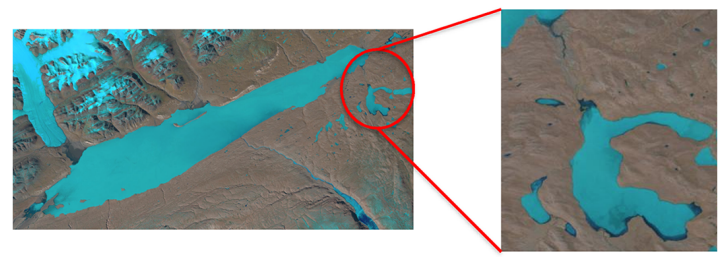

Figure 7. Landsat images acquired at the start of ice break-up showing melt and/or open water adjacent to water inflows: (a) Upper and Lower Murray Lakes (17 June 2007); (b) Buchanan Lake (8 July 1999); (c) Lake L6, (10 July 2003); (d) Lake Hazen and Craig Lake (16 June 2001).

up process. However, the sparse in situ snow accumulation, thickness, and ice type measurements limit the evaluation of the importance of snow in the timing of MO for the lakes in the CAA.

Another factor to be taken into consideration when discussing the timing of MO for lakes is water inflow into the lakes. Eight out of the 11 lakes included in this study have streams flowing into the lake. The origin of the warmer streams flowing into the lakes could be from melting glaciers (i.e., Murray Lakes and Lake Hazen on Northern Ellesmere Island, Buchanan Lake on Axel Heiberg Island) and/or runoff from snowmelt (e.g., lake L4 on Devon Island). The ice break-up of Lake Hazen seems to be initiated by a runoff stream from Craig Lake (Fig. 7).

Similar to MO, timing of WCI is also dependant on air temperature. In order to analyze the relation of WCI to air temperature, the $0^{\circ} \mathrm{C}$ spring isotherm dates were calculated based on the approach described in Bonsal and Prowse (2003). The $0{ }^{\circ} \mathrm{C}$ spring isotherm date is considered as the date when mean daily air temperature rises above $0^{\circ} \mathrm{C}$. Given the large variability in daily air temperature, a 31-day running mean filter is used for the mean daily air temperatures. Lake WCI dates relative to the $0^{\circ} \mathrm{C}$ spring isotherm date, calculated based on the available weather station temperature records and ERA-Interim data, from 1997 to 2011 are shown in Fig. 8. The relation between the timing of WCI dates and $0^{\circ} \mathrm{C}$ spring isotherm date was determined with Spearman's rank correlation coefficient $(R)$. Analysis shows an overall correlation of $R=0.60$ between the WCI date timing and the $0{ }^{\circ} \mathrm{C}$ spring isotherm date for lakes that were ice free every year between 1997 and 2011. As a result of the presence 

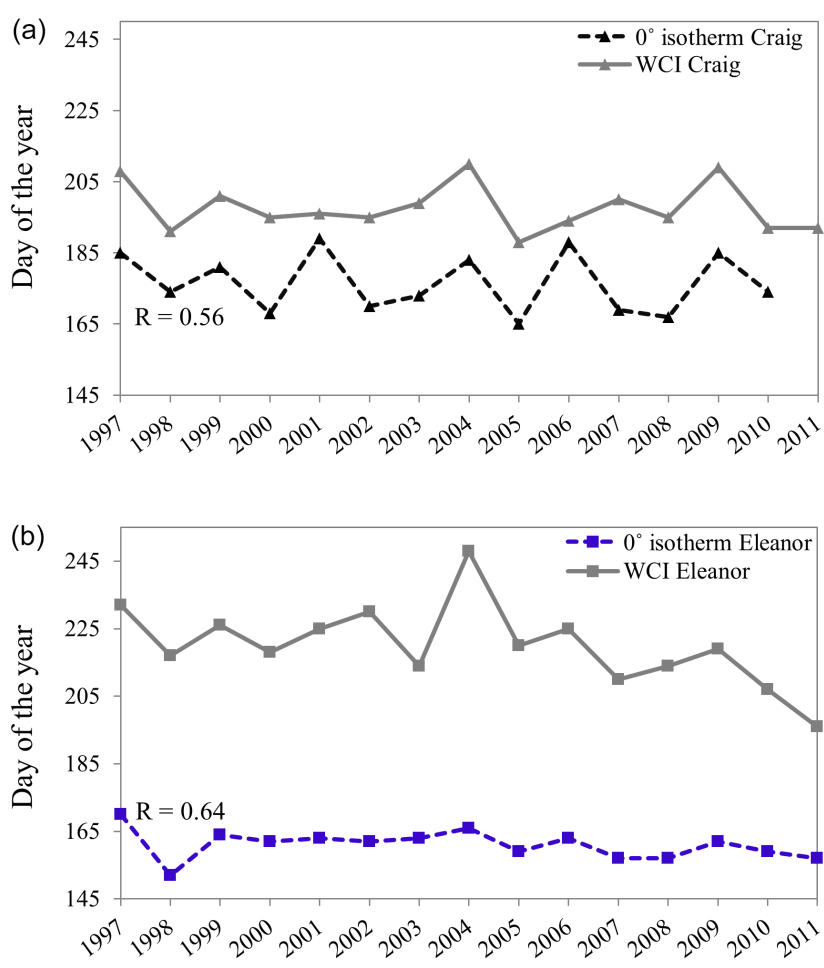

Figure 8. Water-clear-of-ice dates relative to the $0{ }^{\circ} \mathrm{C}$ spring isotherm date between 1997 and 2011 for (a) Craig Lake (polar oasis) and (b) Eleanor Lake (polar desert). Spearman's rank correlation coefficient $(R)$ is also shown.

of an occasional multiyear ice cover, the correlation between $\mathrm{WCI}$ and the $0{ }^{\circ} \mathrm{C}$ spring isotherm date weakens.

The lower correlation for lakes that occasionally maintain an occasional summer ice cover is likely related the limited ability of the gridded data to accurately represent local climate conditions for lakes located further from permanent weather stations. These lakes are influenced by local microclimates due to the effect of the nearby glaciers and high mountains (Woo and Guan, 2006; Keatley et al., 2007). The presence of the Greenland Ice Cap (Alert, Northern Ellesmere Island), glaciers (Northern Ellesmere Island, Devon Island), and high topographic features (mountains $>2200 \mathrm{~m}$ around Lake Hazen and near Eureka) could lead to discrepancies between the weather station and reanalysis data. Hence, given the grid-cell size of the reanalysis data $\left(0.75^{\circ}\right)$, ERA-Interim records for the Northern Ellesmere Island do not always capture the microclimates or warmer/colder climatic episodes that develop in some of the smaller High Arctic areas (L. C., Brown, personal communication, 2014).

AVHRR observations of WCI dates for Lake Hazen and Stanwell Fletcher Lake from 1985 to 2004 reveal earlier break-up by $<10$ days for the former and by 4-6 days for the latter (Latifovic and Pouliot, 2007). The current analysis shows that during the 1997-2011 period, break-up occurred earlier by a total of 12 days for Lake Hazen and by 6 days for Stanwell Fletcher Lake. Considering that break-up is highly correlated with air temperatures (Duguay et al., 2006), the increase in the number of days revealing even earlier WCI dates for Lake Hazen and Stanwell Fletcher Lake is reflective of higher mean air temperatures during 1997-2011 shown by the gridded ERA-Interim data.

Using all available RADARSAT-1/2, ASAR, and Landsat images from the beginning to the end of the break-up period between 1997 and 2011, WCI timing was determined with an accuracy of 1-3 days, 3 days being the longest period with no available satellite imagery from any sensor at the end of break-up. A time series of multiple-sensor acquisitions for Lake Hazen during the 2010 break-up season (Fig. 9) shows the ice cover changes from the beginning to the end of break-up. Changes in the ice cover of Lake Hazen during the 2010 break-up season reflect the lake ice/temperature relation, the decrease in the ice cover fraction being correlated $(R=-0.94)$ with the number of cumulative thawing degree days calculated based on the ERA-Interim daily mean air temperatures (Fig. 10).

The mean duration of the break-up season for Upper Murray Lake is $\mathbf{5 2}$ days and for Lower Murray Lake is $\mathbf{5 5}$ days. Previous findings of ice regimes for Murray Lakes between 1997 and 2007 indicate 16 August (DOY228) as a mean iceoff date for Upper Murray Lake and 24 August (DOY236) for Lower Murray Lake, and an average duration of the melt period of 74 and 81 days, respectively (Cook and Bradley, 2010). The earlier timing of WCI dates and shorter break-up seasons for Murray Lakes shown by the current study are indicative of positive air temperature anomalies at Alert during all years from 2005 to 2011. Earlier positive air temperatures at the beginning of summer and consecutive days with temperatures higher by $2-4{ }^{\circ} \mathrm{C}$ than temperatures recorded during previous break-up seasons of 2007-2011 are likely the main drivers of the earlier WCI dates and shorter break-up periods for Murray Lakes shown in this study.

The greatest changes during the break-up season from 1997 through 2011 were recorded for smaller lakes, in both polar-desert and polar-oasis environments (i.e., lake L4 on Devon Island, Buchanan Lake and Hunting Camp Lake), and the polar-desert type lake, Eleanor. These lakes experienced earlier MO by $20-30$ days, earlier ice minimum dates by 15 30 days, and earlier WCI dates by 15-24 days. These findings suggest that following the considerably higher temperature of polar deserts during recent years (Woo and Young, 2014), polar-desert type lakes are starting to shift into polar-oasis type lakes, the smaller ones showing the shift earlier.

\subsubsection{The multiyear ice cover}

The loss of the perennial/multiyear ice cover for most lakes is mainly a consequence of the warmer air temperatures recorded in the High Arctic during recent decades as recent studies show (Sharp et al., 2011; Zdanowicz et al., 2012; 

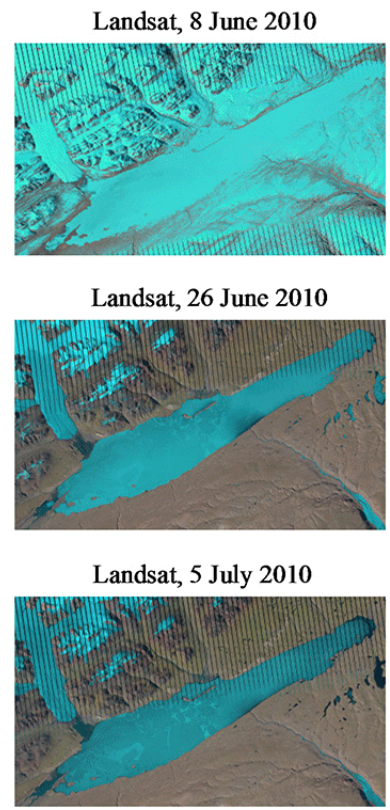

ASAR, 14 July 2010
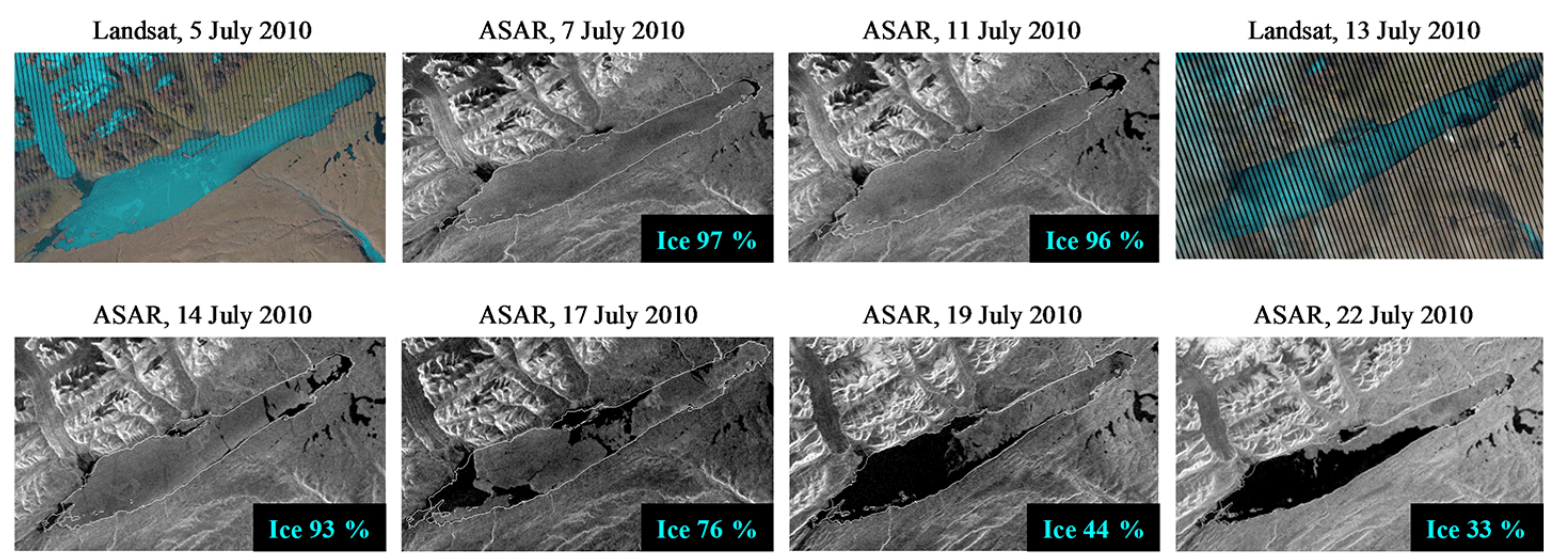

ASAR, 29 July 2010

\section{RADARSAT-2, 31 July 2010}

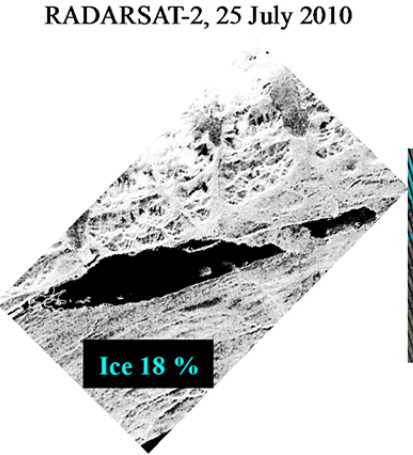

Landsat, 27 July 2010

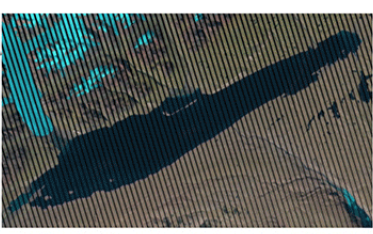

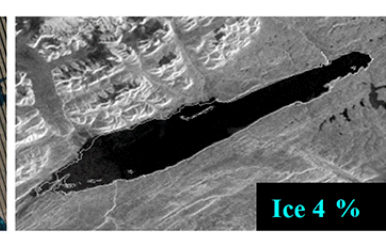

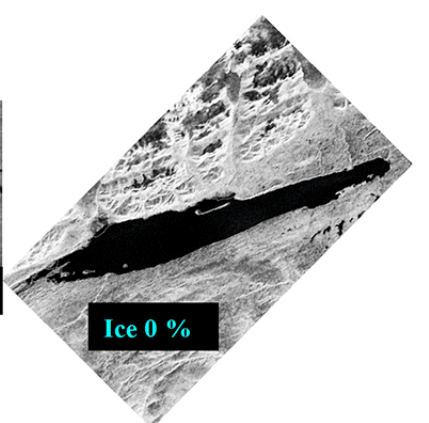

Figure 9. Time series of combined satellite observations (Landsat, ASAR, and RADARSAT-2) for Lake Hazen during the break-up period of 2010. RADARSAT-2 Data and Products ${ }^{\circledR}$ MacDonald, Dettwiler and Associates Ltd., 2010, all rights reserved. RADARSAT is an official trademark of the Canadian Space Agency. Ice fractions for available SAR images are also shown. No ice fractions are shown for Landsat observations as image segmentation was only performed on SAR imagery.

Woo and Young, 2014). In general, during years when the $0{ }^{\circ} \mathrm{C}$ spring isotherm date occurred earlier in the spring, lakes became ice free (e.g., in 1997 the lake L4 on Devon Island maintained a multiyear ice cover in 1997 when the $0{ }^{\circ} \mathrm{C}$ spring isotherm date occurred on DOY170 and, following a
$0{ }^{\circ} \mathrm{C}$ spring isotherm date on DOY 157 , it completely lost its ice cover early in 2011; DOY 204).

Conversely, during years with late $0{ }^{\circ} \mathrm{C}$ spring isotherm date lakes maintained a multiyear ice cover. The persistence of ice throughout the summer into early autumn when it starts refreezing (multiyear ice cover) on occasional (cool) 


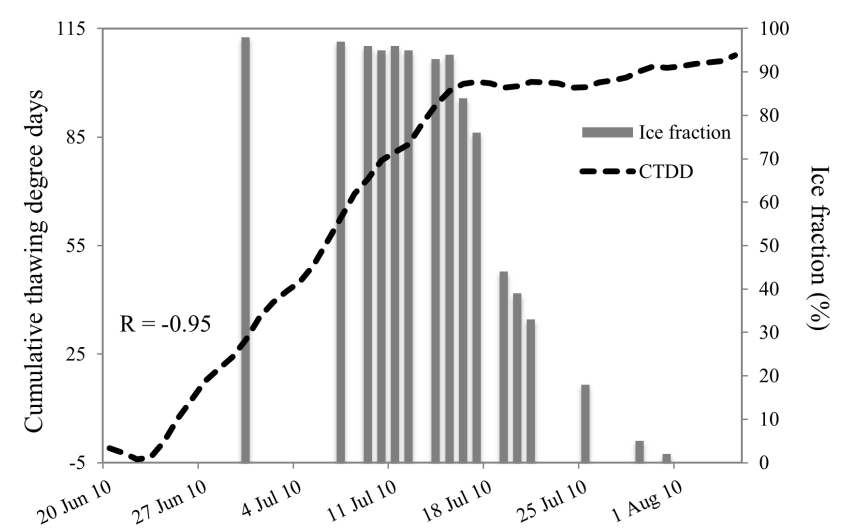

Figure 10. The cumulative thawing degree days and ice fraction for Lake Hazen during the 2010 break-up season.

years in some lakes could be related to a multitude of factors whose individual and/or combined actions allow the lake ice cover to outlast from one season to another. As such, lower spring air temperatures (e.g., 2004) delay ice breakup which combined with lower summer/fall air temperatures promotes a multiyear ice cover. Additionally, the presence of glaciers in the vicinity of some of the study lakes (i.e., Lake Hazen Upper and Lower Murray Lake, lake L4 on Devon Island), through generally persistent low air temperatures, stabilizes the lake ice cover (Doran et al., 1996). Furthermore, the vicinity of a partially frozen Arctic Ocean during (extreme) colder summer seasons cools the atmosphere around the lakes and thus supports the presence of a summer ice cover.

\subsection{Lake ice in a changing cryosphere}

Since the mid-1990s, increasing summer and winter temperatures across the entire Canadian Arctic, and highly noticeable on the eastern side, have been recorded (Zdanowicz et al., 2012). These observations correspond with positive summer-temperature anomalies of $1.5-2{ }^{\circ} \mathrm{C}$ between 2005 and 2009, 3 times higher than the mean of the 1960-2009 period (Fisher et al., 2012). Air temperature changes at high latitudes impact the dynamics and linkages between the different components of the cryosphere and thus also the lake ice cover regimes. As a result of rising mean summer air temperatures in the Canadian High Arctic during recent decades, the snow to total precipitation ratio has been decreasing (Screen and Simmonds, 2011) and the semi-permanent snow cover has been disappearing (Woo and Young, 2014). Despite the enhanced runoff from the CAA glaciers since the 1990s (Gardner et al., 2011; Lenaerts et al., 2013), without the semi-permanent snow, surface and subsurface flows are not properly sustained. A declining semi-permanent snow cover has implications for the local hydrology and could result in the disappearance of wetlands and ponds in low-precipitation years when the semi-permanent snow is the main source of runoff. Additionally, it also affects the local ecology through changes in the habitat and food availability and the vegetation cover. Moreover, following accelerated snow ablation consequent to increased rainfall, early snowmelt occurs during warm summers, exposing the underlying permafrost layer to more solar radiation and thus deepening the active layer (Woo and Young, 2014).

\subsubsection{Changes in near-surface air and surface temperature}

The $1 \mathrm{~km}$ resolution combined MODIS Aqua/Terra LST maps represent a valuable tool in obtaining consistent observations of "surface skin" temperature over land at high latitudes. MODIS observations acquired during the break-up season of 2 extreme years, 2004 (negative air temperature anomalies), and 2011 (positive air temperature anomalies) show up to $5^{\circ} \mathrm{C}$ differences in the mean summer air temperatures of the 2 years, over all study sites (Fig. 11).

Differences in the surface "skin" temperature from MODIS discriminate the warmer land areas from the colder ones. During years with negative annual air temperature anomalies, these differences range from 5 to $15^{\circ} \mathrm{C}$ for the polar-oasis areas around Lake Hazen on Northern Ellesmere Island and Buchanan Lake on Axel Heiberg Island and from 1 to $4{ }^{\circ} \mathrm{C}$ for the polar-oases areas around lake L4 on Devon Island and Hunting Camp Lake on Bathurst Island. The air temperature differences between the investigated polar oases and the surrounding areas during years with positive annual air temperatures range from 10 to $19^{\circ} \mathrm{C}$ around lake Hazen and Buchanan Lake and from 9 to $16^{\circ} \mathrm{C}$ for areas around lakes L6 and L7.

In June 2004, the areas around Lake Hazen and Buchanan Lake experienced higher temperatures than the surrounding areas that are controlled by a typical polar-desert climate by $5-12{ }^{\circ} \mathrm{C}$. No air temperature difference was observed in the case of areas around lakes L4 and Hunting Camp Lake during the same month. In 2011, the June air temperature differences between the warmer polar oases and surrounding areas ranged from 3 to $4{ }^{\circ} \mathrm{C}$ (lake L4 and Hunting Camp Lake) and 10 to $16^{\circ} \mathrm{C}$ (Lake Hazen and Buchanan Lake).

During the month of July, all areas around the investigated polar oases experienced higher air temperature than the surrounding areas. In 2004, these differences ranged from $3-4{ }^{\circ} \mathrm{C}$ (lake L and Hunting Camp Lake) to $3-11^{\circ} \mathrm{C}$ (Lake Hazen and Buchanan Lake). These differences were considerably higher in 2011 and ranged from $12-15^{\circ} \mathrm{C}$ (lakes L6 and L7) to $9-19^{\circ} \mathrm{C}$ (Lake Hazen and Buchanan Lake).

During the month of August 2004 and 2011, no noticeable "skin" temperature differences were observed for areas around lakes L4 and Hunting Camp Lake in comparison to the usually colder surrounding areas. Air temperatures around Lake Hazen and Buchanan Lake during the same month were higher than the neighboring areas by $9-12^{\circ} \mathrm{C}$ in 2004 and by $13-16^{\circ} \mathrm{C}$ in 2011 . 

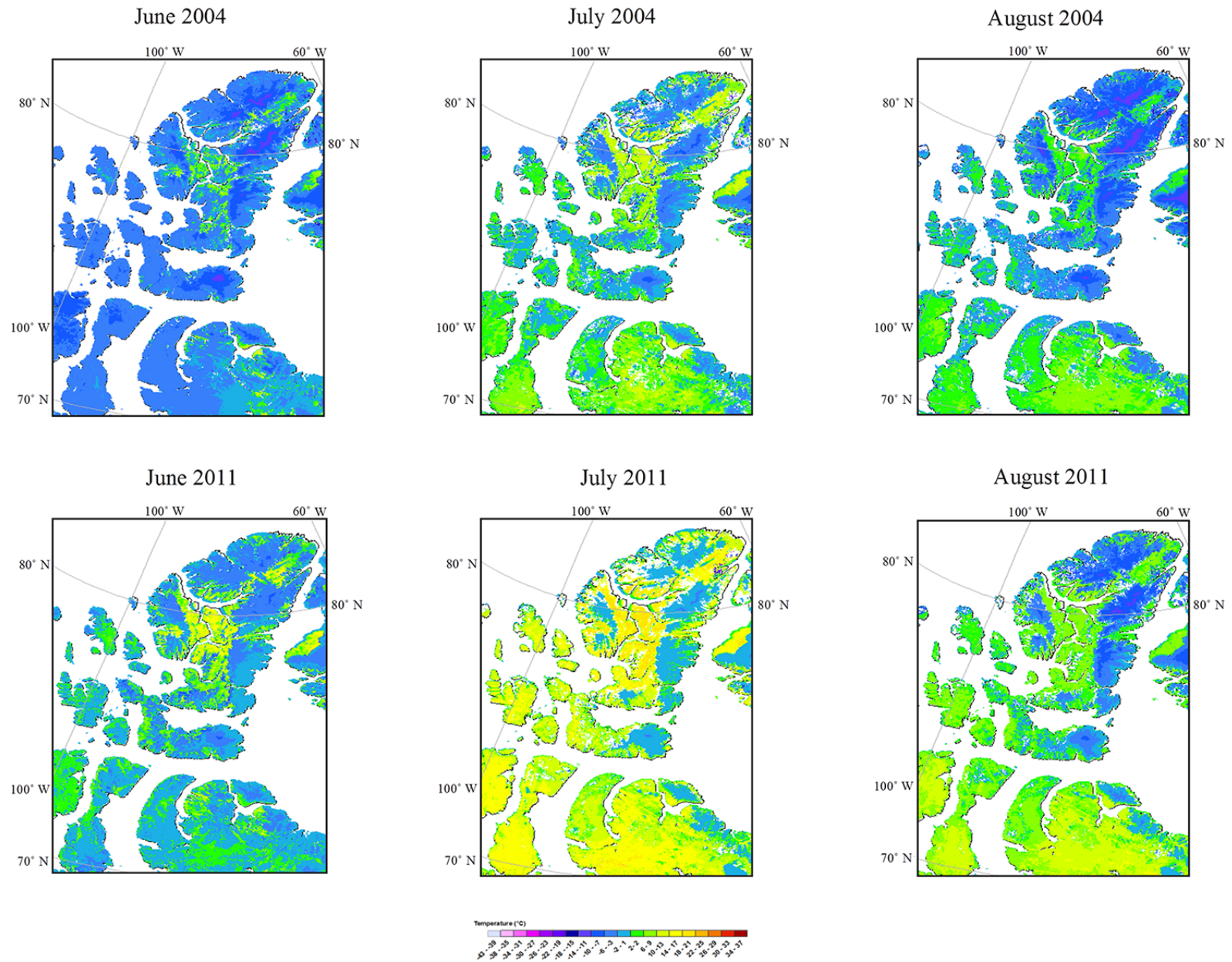

Figure 11. Mean land surface temperature derived from
and August of 2004 (colder year) and 2011 (warmer year).

Analysis of MODIS data shows that the greatest differences in surface temperature of polar oases and those polardesert locations investigated in the current study occur in June and July, with significant surface temperature differences during years with higher air temperature anomalies of the same month. Moreover, differences in surface temperature between polar oases and the surrounding polar-desert environments is considerably higher around Lake Hazen on Northern Ellesmere Island and Buchanan Lake on Axel Heiberg Island and less around lake L4 on Devon Island and Hunting Camp Lake on Bathurst Island. In years with high positive air temperature anomalies, these polar "hot spots" extend over larger areas and could be impacting the otherwise typical polar-desert climate of the neighboring areas.

Analysis of air temperature as recorded at the weather stations with available data reveals that temperature anomalies during the same month of the 2 years are greatest during the month of June at all stations and smallest in August when solar radiation drops off rapidly as a result of a declining solar angle (Woo and Young, 1996). The smallest positive air temperature anomaly between 2004 and 2011 was recorded in July at Alert $\left(0.67^{\circ} \mathrm{C}\right)$, and the greatest positive anomaly was observed in July at Resolute $\left(5.09^{\circ} \mathrm{C}\right)$. In 2004 , delayed WCI dates were observed for most lakes, with Craig Lake, lake L11 on Baffin Island, Hunting Camp Lake on Bathurst Island, and Eleanor Lake experiencing the latest WCI dates during the 15-year record. Lake Hazen and lake L4 on Devon Island also maintained a multiyear ice cover throughout the 2004 summer. Conversely, in 2011 earlier MO and WCI was observed for most lakes, with extreme earlier WCI dates for Lake Buchanan, lake L4, Hunting Camp Lake, Eleanor Lake, lake L9, and lake L11. Multiyear ice was not observed on any of the 11 lakes at the end of the 2010/11 ice season.

\subsubsection{Changes in atmospheric/oceanic circulation patterns}

Air temperatures at high latitudes are associated with changes in the coupled atmosphere-ocean system (Trenberth and Hurrell, 1994). Warmer air temperatures and a higher 
Arctic troposphere will continue to reduce the pressure gradient between northern and southern latitudes and will lead to substantial changes in atmospheric circulation patterns (Watanabe et al., 2006). Extreme phases of atmospheric circulation patterns, also known as teleconnections, have been shown to influence ice phenology of lakes in the Northern Hemisphere (Bonsal et al., 2006), such as the major shift in the Pacific Decadal Oscillation (PDO) in the mid-1970s toward a positive phase when North American lakes experienced earlier break-up and shorter ice seasons (Benson et al., 2000) or the strong positive phase of El Niño-Southern Oscillation (ENSO) in 1998 that resulted in extreme ice events (i.e., later ice freeze-up and earlier break-up, anomalously thin ice) for many of the lakes in the High Arctic (Atkinson et al., 2006) and when none of the study lakes maintained a multiyear ice cover. The North Atlantic Oscillation (NAO) and the Arctic Oscillation (AO), highly related to each other, also play a significant role in the winter/early spring (November-April) Arctic atmosphere, NAO in particular influencing the air temperatures on the eastern side of North America (Bonsal et al., 2006). The relation between Arctic lake ice phenology and NAO/AO patterns during recent years has not yet been thoroughly investigated. However, it has been hypothesized that the shorter ice seasons in northeastern Canada and Baffin Bay are likely associated with the persistent positive air temperature anomalies in the area from around 2000 (Prowse et al., 2011), coinciding with a trend toward a more negative $\mathrm{NAO} / \mathrm{AO}$ values (Overland and Wang, 2005).

The lack of a strong correlation between ice break-up of High Arctic lakes and teleconnections from 1997 through 2011 as indicated by a preliminary analysis (not shown) could be explained by the fact that neither PDO nor the $\mathrm{NAO} / \mathrm{AO}$ has been in a phase to contribute to the Arctic warming during the past several years (AMAP, 2011). On a background of increased warming at higher latitudes, the previous strong correlation between $\mathrm{AO}$ and ice regimes of lakes north of $65^{\circ}$ (Bonsal and Prowse, 2003) could weaken in the forthcoming decades. However, in order to determine the impact that atmospheric circulation patterns have had on ice phenology during recent years, a more comprehensive analysis is needed.

\section{Summary and conclusions}

This study provides an assessment of lake ice conditions in the central and eastern Canadian High Arctic and reveals changes in the break-up dates and the summer ice cover that these lakes experienced between 1997 and 2011. Analysis of the available SAR and Landsat data from 1997 to 2011 indicates that the start of ice break-up (melt onset) is occurring by 14-39 days earlier for polar-oasis lakes (out of five investigated polar-oasis lakes, one showed a statistically significant trend at the 0.01 level and two at the 0.05 level) and by $3-$
23 days earlier for polar-desert lakes (out of six investigated polar-desert lakes, two showed a statistically significant trend at the 0.05 level). Changes were also observed in the summer ice minimum, with ice generally disappearing earlier on all lakes, by 9-30 days earlier in polar-oasis environments (out of five investigated polar-oasis lakes, one showed a statistically significant trend at the 0.05 level and one at the 0.1 level) and by 2-19 earlier in polar-desert environments (out of six investigated polar-desert lakes, one showed a statistically significant trend at the 0.05 level). Timing of the WCI dates ranges from 9 to 24 days earlier in polar-oasis environments (out of five investigated polar-oasis lakes, one showed a statistically significant trend at the 0.01 level) and from 2 to 20 days earlier in polar-desert environments (out of six investigated polar-desert lakes, one showed a statistically significant trend at the 0.05 level). The only lake with later WCI dates is Lower Murray Lake (13 days, statistically significant at the $>0.1$ level).

During the 15 -year period covered by this study, the MO and WCI dates occurred earlier for all 11 lakes, with the exception of Lower Murray Lake on Northern Ellesmere Island that, despite experiencing earlier MO, had an ice cover lasting longer into the summer or even occasionally persisting from one year to another. The lakes with the greatest changes in the timing of MO date were Buchanan Lake on Axel Heiberg Island (24 days early), Eleanor Lake on Cornwallis Island (20 days early), lake L7 on Bathurst Island (15 days early), Lake Hazen (9 days early), and lake L4 on Devon Island ( 8 days early). Earlier summer ice minimum was also observed on these lakes. Given that with the exception of Eleanor Lake, the lakes with the shortest ice seasons are located in polar-oasis areas, environments dominated by milder temperatures, comes to reinforce the strong relation between air temperature and lake ice break-up. The increasing positive air temperature anomalies are likely the cause of multiyear ice loss for lakes. Lakes that preserved their ice cover from one season to another on a consistent basis (e.g., Lake Hazen, Stanwell Fletcher Lake) in previous decades are transitioning toward a seasonal ice cover, with sparse or no multiyear ice seasons. Some of the lakes on Northern Ellesmere Island (i.e., Lake Hazen and Murray Lakes), along with lake L4 on Devon Island and Stanwell Fletcher Lake are the only lakes with observed occasional multiyear ice. From 2007 to 2011, Lake Hazen and Murray Lakes were the only ones with observed multiyear ice cover in 2009. However, given the short record of this study, these results are indicative of a possible change in lake ice regimes during the 15-year period and likely are also reflective of yearly variability and variability over the study area.

In an Arctic that has warmed during recent decades and that will likely continue to be driven by above-normal air temperatures, shorter ice seasons, with later freeze-up and earlier break-up dates, complete loss the perennial ice cover (Brown and Duguay, 2011), and major biological changes 
within the High Arctic lakes are predicted to persist in forthcoming decades.

Studies suggest that consequent to ice loss and longer open-water seasons, Arctic lakes and ponds have the potential to experience a large leap in productivity and more rapid nutrient cycling (Perren et al., 2003; Smol and Douglas, 2007; Paul et al., 2010). A possible scenario consequent to a reduced ice cover involves abundance of periphytic diatoms in shallow lakes (Smol et al., 2005), diversification of the planktonic flora (Keatley et al., 2008), and an overall increase of the primary production rate (Smol et al., 2005). Lakes within the polar deserts may virtually start to respond and act like those within polar oases consequent to the changing climate conditions (Young and Abnizova, 2011). Studying the ice phenology of lakes that are presently located in polar-oasis environments could provide an insight as to how the ice conditions of polar-desert lakes may be in the near future.

The Arctic cryosphere is a complex system driven by strong interactions among the atmosphere, land, and ocean. Under projected amplified warming of polar regions, ice break-up of inland lakes will be prone to a greater change as ice decay is more responsive to changes in air temperature (Brown and Duguay, 2011). Considering the dynamic nature of the ocean-atmosphere-land linkages, changes within the lake ice cover are likely to be more prominent, result in more extreme ice conditions associated with warmer events (e.g., extremely late freeze-up, extremely early break-up; Benson et al., 2011), and shift from a perennial/multiyear to a seasonal ice cover.

The results presented in this paper document changes in the ice cover of lakes in the Canadian High Arctic in recent years, as observed by a combination of SAR and optical sensors, and present a preview of changes that Arctic lakes are likely to undergo in future decades. The combination of radar satellite missions, the new Sentinel-1A/B and the forthcoming RADARSAT constellation, and the recently launched optical Sentinel 2-A Multi-Spectral instrument, with frequent revisit times, will be invaluable tools that will enable consistent monitoring of High Arctic lakes in a dynamic and rapidly changing climate. The 15-year ice records for the observed 11 lakes in the CAA set the baseline for a long-term monitoring database for High Arctic lakes that can be consolidated through observations from future satellite missions.

Acknowledgements. This work was supported by a Discovery Grant from the Natural Sciences and Engineering Research Council of Canada (NSERC) to Claude Duguay. The authors would like to thank our colleague, Homa Kheyrollah Pour, for providing the MODIS LST maps. We are also grateful to Andrew Wong (University of Waterloo) for helping with processing the overwhelming amount of RADARSAT-1/2 data. We would like to extend our gratitude to Kevin Kang for sorting the RADARSAT data. Additionally, the authors would like to thank to Laura Brown (University of Toronto) for the personal notes exchanged and for kindly sharing her unpublished work results. We are also grateful to two anonymous reviewers whose suggestions improved the paper. We would like to extend our gratitude to the European Space Agency (ESA) for providing the ASAR data and to ESA's Grid Processing on Demand (GPOD) team led by Roberto Cuccu and Giovanni Sabatini for pre-processing the ASAR images. The RADARSAT-1/2 imagery was downloaded from the Polar Data Catalogue. RADARSAT-1 images are copyright the Canadian Space Agency (CSA) 1997-2010. The RADARSAT-2 images were provided by the Canadian Ice Service (CIS). RADARSAT-2 Data and Products ${ }^{\odot}$ MacDonald, Dettwiler and Associates Ltd., 20082011, all rights reserved. RADARSAT is an official trademark of the Canadian Space Agency. Landsat images were provided by the US Geological Survey. MODIS Aqua and Terra Land Surface Temperature and Emissivity data were acquired from the NASA Land Processes Distributed Active Archive Center (LP DAAC).

Edited by: P. Marsh

\section{References}

ACIA (Arctic Climate Impact Assessment): Impacts of a Warming Arctic: Arctic Climate Impact, Cambridge University Press, New York, Overview Report, p. 1042, 2005.

Adams, W. P., Doran, P. T., Ecclestone, M., Kingsbury, C. M., and Allan, C. J.: A rare second year - Lake ice cover in the Canadian High Arctic, Arctic, 42, 299-306, 1989.

Aiken, S. G., Dallwitz, M. G., Consaul, L. L., Mcjannet, C. L., Boles, R. L., Argus, G. W., Gillett, J. M., Scott, P. J., Elven, R., Leblanc, M. C., Gillespie, L. J., Brysting, A. K., Solstad, H., and Harris, J. G.: Flora of the Canadian Arctic Archipelago: Descriptions, Illustrations, Identification, and Information Retrieval, NRC Research Press, National Research Council of Canada, Ottawa, available at: http://nature.ca/aaflora/data, last access: 10 July 2015, 1999.

AMAP (Arctic Monitoring and Assessment Programme): Snow, Water, Ice and Permafrost in the Arctic (SWIPA) 2011, AMAP, Oslo, 2011.

Arp, C. D., Jones, B. M., and Grosse, G.: Recent lake ice-out phenology within and among lake districts of Alaska, U.S.A., Limnol. Oceanogr., 58, 2013-2028, 2013.

Assini, J. and Young, K. L.: Snow cover and snowmelt of an extensive High Arctic wetland: spatial and temporal seasonal patterns, Hydrolog. Sci. J., 57, 738-755, 2012.

Atkinson, D. E., Brown, R., Alt, B., Agnew, T., Bourgeois, J., Burgess, M., Duguay, C., Henry, G., Jeffers, S., Koerner, R., Lewkowicz, A. G., McCourt, S., Melling, H., Sharp, M., Smith, S., Walker, A., Wilson, K., Wolfe, S., Woo, M.-k., and Young, K. L.: Canadian cryospheric response to an anomalous warm summer: A synthesis of the Climate Change Action Fund Project "The state of the Arctic cryosphere during the extreme warm summer of 1998", Atmos. Ocean, 44, 347-375, doi:10.3137/ao.440403, 2006.

Belzile, C., Vincent, W. F., Gibson, J. A. E., and Van Hove, P.: Biooptical characteristics of the snow, ice, and water column of a perennially ice-covered lake in the High Arctic, Can. J. Fish. Aquat. Sci., 58, 2405-2418, 2001. 
Benson, B. J., Magnuson, J. J., Jacob, R. L., and Fuenger, S. L.: Response of lake ice breakup in the Northern Hemisphere to the 1976 interdecadal shift in the North Pacific, Verhandlungen des Internationalen Verein Limnologie, 27, 2770-2774, 2000.

Benson, B. J., Magnuson, J. J., Jensen, O. P., Card, V. M., Hodgkins, G., Korhonen, J., Livingstone, D. M., Stewart, K. M., Weyhenmeyer, G. A., and Granin, N. G.: Extreme events, trends, and variability in Northern Hemisphere lake-ice phenology (18552005), Climatic Change, 112, 299-323, doi:10.1007/s10584011-0212-8, 2011.

Bliss, L. C.: Introduction, in: Truelove Lowland, Devon Island, Canada: A High Arctic ecosystem, University of Alberta Press, Edmonton, 1-12, 1977.

Bonsal, B. R. and Prowse, T. D.: Trends and variability in spring and autumn $0{ }^{\circ} \mathrm{C}$-isotherm dates over Canada, Climatic Change, 57, 341-358, 2003.

Bonsal, B. R., Prowse, T. D., Duguay, C. R., and Lacroix, M. P.: Impacts of large-scale teleconnections on freshwater-ice break/freeze-up dates over Canada, J. Hydrol., 330, 340-353, 2006.

Brown, L. C. and Duguay, C. R.: The fate of lake ice in the North American Arctic, The Cryosphere, 5, 869-892, doi:10.5194/tc5-869-2011, 2011.

Coakley, J. P. and Rust, B. R.: Sedimentation in an Arctic lake, J. Sediment. Petrol., 38, 1290-1300, 1968.

Cook, T. L. and Bradley, R. S.: An analysis of past and future changes in the ice cover of two high-arctic lakes based on synthetic aperture radar (SAR) and Landsat imagery, Arct. Antarct. Alp. Res., 42, 9-18, 2010.

Courtin, G. M. and Labine, C. L.: Microclimatological studies on Truelove Lowland, in: Truelove Lowland, Devon Island, Canada: a High Arctic Ecosystem edited by: Bliss, L. C., University of Alberta Press, Edmonton, 73-106, 1977.

Dee, D. P., Uppala, S. M., Simmons, A. J., et al.: The ERA-Interim reanalysis: configuration and performance of the data assimilation system, Q. J. Roy. Meteor. Soc., 137, 553-597, 2011.

Derksen, C., Smith, S. L., Sharp, M., Brown, L., Howell, S., Copland, L., Mueller, D. R., Gauthier, Y., Fletcher, C. G., Tivy, A., Bernier, M., Bourgeois, J., Brown, R., Burn, C. R., Duguay, C., Kushner, P., Langlois, A., Lewkowicz, A. G., Royer, A., and Walker, A.: Variability and change in the Canadian cryosphere, Climatic Change, 115, 59-88, 2012.

Doran, P. T., McKay, C. P., Adams, W. P., English, M. C., Wharton Jr., R. A., and Meyer, M. A.: Climate forcing and thermal feedback of residual lake-ice covers in the high Arctic, Limnol. Oceanogr., 41, 839-848, 1996.

Duguay, C. R., Pultz, T. J., Lafleur, P. M., and Drai, D.: RADARSAT backscatter characteristics of ice growing on shallow sub-Arctic lakes, Churchill, Manitoba, Canada, Hydrol. Process., 16, 16311644, 2002.

Duguay, C. R., Prowse, T. D., Bonsal, B. R., Brown, R. D., Lacroix, M. P., and Ménard, P.: Recent trends in Canadian lake ice cover, Hydrol. Process., 20, 781-801, 2006.

Edlund, S. A. and Alt, B. T.: Regional congruence of vegetation and summer climate patterns in the Queen Elizabeth Islands, Northwest Territories, Canada, Arctic, 42, 3-23, 1989.

Environment Canada: National climate data and information archive, available at: http://climate.weatheroffice.gc.ca/ climatenormals, last access: 29 June 2015, 2011.
Fisher, D., Zheng, L., Burgess, D., Zdanowicz, C., Kinnard, C., Sharp, M., and Bourgeois, J.: Recent melt rates of Canadian Arctic ice caps are the highest in four millennia, Global Planet. Change, 84-85, 3-7, 2012.

France, R. L.: The Lake Hazen Trough: A late winter oasis in a polar desert, Biol. Conserv., 63, 149-151, 1993.

Freedman, B., Svoboda, J., and Henry, G. H. R.: Alexandra Fiord: An ecological oasis in the polar desert, in: Ecology of a polar oasis: Alexandra Fiord, Ellesmere Island, Canada, edited by: Svoboda, J. and Freedman, B., Captus University Publications, Toronto, 1-12, 1994.

Futter, M. N.: Patterns and trends in southern Ontario lake ice phenology, Environ. Monit. Assess., 88, 431-444, 2003.

Gardner, A. S., Moholdt, G., Wouters, B., Wolken, G. J., Burgess, D. O., Sharp, M., Cogley, G., Braun, C., and Labine, C.: Sharply increased mass loss from glaciers and ice caps in the Canadian Arctic Archipelago, Nature, 473, 357-360, doi:10.1038/nature10089, 2011.

Geldsetzer, T. and Van Der Sanden, J. J.: Identification of polarimetric and nonpolarimetric C-band SAR parameters for application in the monitoring of lake ice freeze-up, Can. J. Remote Sens., 39, 263-275, 2013.

Geldsetzer, T., Van Der Sanden, J., and Brisco, B.: Monitoring lake ice during spring melt using RADARSAT-2 SAR, Can. J. Remote Sens., 36, S391-S400, 2010.

Hall, D. K.: Remote sensing of snow and ice using imaging radar, in: Principles and Applications of Imaging Radar, edited by: Henderson, F. M. and Lewis, A. J., Principles and Applications of Imaging Radar, John Wiley and Sons, Inc., New York, 677-698, 1998.

Hattersley-Smith, G.: North of latitude eighty, Defence Research Board, Ottawa, Canada, 1974.

Heron, R. and Woo, M.-K.: Decay of a high Arctic lake-ice cover: observations and modelling, J. Glaciol., 40, 283-292, 1994.

Hess, A., Iyer, H., and Malm, W.: Linear trend analysis: A comparison of methods, Atmos. Environ., 35, 5211-5222, 2001.

Hirsch, R. M., Slack, J. R., and Smith, R. A.: Techniques of trend analysis for monthly water quality data, Water Resour. Res., 20, 727-732, 1982.

IPCC (Intergovernmental Panel on Climate Change): Climate Change 2013: The Physical Science Basis, Contribution of Working Group I to the Fifth Assessment Report of the Intergovernmental Panel on Climate Change, edited by: Stocker, T. F., Qin, D., Plattner, G.-K., Tignor, M., Allen, S. K., Boschung, J., Nauels, A., Xia, Y., Bex, V., and Midgley, P. M., Cambridge University Press, New York, 1535 pp., 2013.

Jeffries, M. O. and Krouse, H. R.: Isotopic and chemical investigations of two stratified lakes in the Canadian Arctic, Zeitschrift für Gletscherkunde und Glazialgeologie, 21, 71-78, 1985.

Jeffries, M. O., Morris, K., and Liston, G. E.: A method to determine lake depth and water availability on the North Slope of Alaska with spaceborne imaging radar and numerical ice growth modelling, Arctic, 49, 367-374, 1996.

Jeffries, M. O., Morris, K., and Kozlenko, N.: Ice characteristics and processes, and remote sensing of frozen rivers and lakes, in: Remote sensing in northern hydrology; measuring environmental change, edited by: Duguay, C. R. and Pietroniro, A., American Geophysical Union, Washington, DC, USA, 163, 63-90, doi:10.1029/163GM05, 2005. 
Keatley, B. E., Douglas, M. S. V., and Smol, J. P.: Limnological characteristics of a High Arctic oasis and comparisons across northern Ellesmere Island, Arctic, 60, 294-308, 2007.

Keatley, B. E., Douglas, M. S. V., and Smol, J. P.: Prolonged ice cover dampens diatom community responses to recent climatic change in High Arctic lakes, Arct. Antarct. Alp. Res., 40, 364372, 2008.

Kheyrollah Pour, H., Duguay, C. R., Solberg, R., and Rudjord, Ø.: Impact of satellite-based lake surface observations on the initial state of HIRLAM. Part I: evaluation of remotely-sensed lake surface water temperature observations, Tellus A, 66, 21534, doi:10.3402/tellusa.v66.21534, 2014.

Latifovic, R. and Pouliot, D.: Analysis of climate change impacts on lake ice phenology in Canada using the historical satellite data record, Remote Sens. Environ., 106, 492-507, 2007.

Lee, J.-S.: Digital image enhancement and noise filtering by use of local statistics, IEEE T. Pattern Anal., 2, 165-168, 1980.

Lenaerts, J. T., Van Angelen, J. H., Van Den Broeke, A. S., Gardner, A. S., Wouters, B., and Van Meijgaard, E.: Irreversible mass loss of Canadian Arctic Archipelago glaciers, Geophys. Res. Lett., 40, 870-874, 2013.

Michelutti, N., McCleary, K., Douglas, M. S. V., and Smol, J. P.: Comparison of freshwater diatom assemblages from a High Arctic oasis to nearby polar desert sites and their application to environmental inference models, J. Phycol., 49, 41-53, 2013.

Morris, K., Jeffries, M. O., and Weeks, W. F.: Ice processes and growth history on Arctic and sub-Arctic lakes using ERS-1 SAR data, Polar Rec., 31, 115-128, 1995.

Mueller, D. R., Van Hove, P., Antoniades, D., Jeffries, M. O., and Vincent, W. F.: High Arctic lakes as sentinel ecosystems: Cascading regime shifts in climate, ice cover, and mixing, Limnol. Oceanogr., 54, 2371-2385, 2009.

Overland, J. E. and Wang, M. Y.: The third Arctic climate pattern: 1930s and early 2000s, Geophys. Res. Lett., 32, L23808, doi:10.1029/2005GL024254, 2005.

Palecki, M. A. and Barry, R. G.: Freeze-up and break-up of lakes as an index of temperature changes during the transition seasons: a case study for Finland, J. Appl. Meteorol. Clim., 25, 893-902, 1986.

Paquette, M., Fortier, D., Mueller, D. R., Sarrazin, D., and Vincent, W. F.: Rapid disappearance of perennial ice on Canada's most northern lake, Geophys. Res. Lett., 42, 1433-1440, 2015.

Paul, C. A., Douglas, M. S. V., and Smol, J. P.: Diatom-inferred Holocene climatic and environmental changes in an unusually subsaline High Arctic Nunatak pond on Ellesmere Island (Nunavut, Canada), J. Paleolimnol., 44, 913-929, 2010.

Perren, B., Bradley, R. S., and Francus, P.: Rapid Lacustrine Response to Recent High Arctic Warming: A Diatom Record from Sawtooth Lake, Ellesmere Island, Nunavut, Arct. Antarct. Alp. Res., 35, 271-278, 2003.

Prowse, T. D., Alfredsen, K., Beltaos, S., Bonsai, B. R., Duguay, C. R., Korhola, A., McNamara, J., Vincent, W. F., Vuglinsky, V., Walter Anthony, K. M., and Weyhenmeyer, G. A.: Past and future changes in Arctic lake and river ice, Ambio, 40, 53-62, doi:10.1007/s13280-011-0216-7, 2011.

Screen, J. A. and Simmonds, I.: Erroneous Arctic temperature trends in the ERA-40 reanalysis: a closer look, J. Climate, 24, 2620-2627, 2011.
Sen, P. K.: Estimates of the regression coefficient based on Kandall's tau, J. Am. Stat. Assoc., 63, 1379-1389, 1968.

Sharp, M., Burgess, D. O., Cogley, J. G., Ecclestone, M., Labine, C., and Wolken, G. J.: Extreme melt on Canada's Arctic ice caps in the 21st century, Geophys. Res. Lett., 38, L11501, doi:10.1029/2011GL047381, 2011.

Simmons, A. J. and Poli, P.: Arctic warming in ERA-Interim and other analyses, Q. J. Roy. Meteor. Soc., 141, 1147-1162, 2014.

Simmons, A. J., Willett, K. M., Jones, P. D., Thorne, P. W., and Dee, D. P.: Low-frequency variations in surface atmospheric humidity, temperature and precipitation: Inferences from reanalyses and monthly gridded observational datasets, J. Geophys. Res., 115, D01110, doi:10.1029/2009JD012442, 2010.

Smith, L. C.: Trends in Russian Arctic river-ice formation and break-up, 1917 to 1994, Phys. Geogr. 21, 46-56, 2000.

Smol, J. P. and Douglas, M. S. V.: Crossing the final ecological threshold in High Arctic ponds, P. Natl. Acad. Sci. USA, 104, 12395-12397, 2007.

Smol, J. P., Wolfe, A. P., Birks, H. J. B., Douglas, M. S. V., Jones, V. J., Korhola, A., Pienitz, R., Rühland, K., Sorvari, S., Antoniades, D., Brooks, S. J., Fallu, M.-A., Hughes, M., Keatley, B. E., Laing, T. E., Michelutti, N., Nazarova, L., Nyman, M., Paterson, A. M., Perren, B., Quinlan, R., Rautio, M., Saulnier-Talbot, E., Siitonen, S., Solovieva, N., and Weckström, J.: Climate-driven regime shifts in the biological communities of Arctic lakes, P. Natl. Acad. Sci. USA, 102, 4397-4402, 2005.

Sobiech, J. and Dierking, W.: Observing lake- and river-ice decay with SAR: advantages and limitations of the unsupervised $k$-means classification approach, Ann. Glaciol., 54, 65-72, doi:10.3189/2013AoG62A037, 2013.

Surdu, C. M., Duguay, C. R., Brown, L. C., and Fernández Prieto, D.: Response of ice cover on shallow lakes of the North Slope of Alaska to contemporary climate conditions (19502011): radar remote sensing and numerical modeling data analysis, The Cryosphere, 8, 167-180, 2014.

Surdu, C. M., Duguay, C. R., Kheyrollah Pour, H., and Brown, L. C.: Ice freeze-up and break-up detection of shallow lakes in Northern Alaska with spaceborne SAR, Remote Sensing, 7, 6133-6159, 2015.

Svoboda, J. and Freedman, B.: Ecology of a High Arctic Lowland Oasis Alexandra Fiord $\left(78^{\circ} 53^{\prime} \mathrm{N}, 75^{\circ} 55^{\prime} \mathrm{W}\right)$, Ellesmere Island, NWT, Canada, University of Toronto, Department of Botany, Toronto, Canada, 1981.

Tabari, H., Marofi, S., Aeini, A., Talaee, P. H., Mohammadi, K.: Trend analysis of reference evapotranspiration in the Western half of Iran, Agr. Forest Meteorol., 151, 128-136, 2011.

Trenberth, K. E. and Hurell, J. W.: Decadal atmosphere-ocean variations in the Pacific, Clim. Dynam., 9, 303-319, 1994.

Veillette, J., Martineau, M.-J., Antoniades, D., Sarrazin, D., and Vincent, W. F.: Effects of loss of perennial lake ice on mixing and phytoplankton dynamics: Insights from High Arctic Canada, Ann. Glaciol., 51, 56-70, 2010.

Watanabe, E., Wang, J., Sumi, A., and Hasumi, H.: Arctic Dipole anomaly and its contribution to sea ice export from the Arctic Ocean in the 20th century, Geophys. Res. Lett., 33, L23703, doi:10.1029/2006GL028112, 2006.

Williamson, C. E., Dodds, W., Kratz, T. K., and Palmer, M. A.: Lakes and streams as sentinels of environmental change in ter- 
restrial and atmospheric processes, Front. Ecol. Environ., 6, 247$254,2008$.

Woo, M.-K. and Guan, X. J.: Hydrological Connectivity and Seasonal Storage Change of Tundra Ponds in a Polar Oasis Environment, Canadian High Arctic, Permafrost Periglac., 17, 309-323, 2006.

Woo, M.-K. and Marsh, P.: Analysis of error in the determination of snow storage for small High Arctic basins, J. Appl. Meteorol., 17, 1537-1541, 1978.

Woo, M.-K. and Young, K. L.: Summer solar radiation in the Canadian High Arctic, Arctic, 49, 170-180, 1996.

Woo, M.-K. and Young, K. L.: Hydrology of a small drainage basin with polar oasis environment, Fosheim Peninsula, Ellesmere Island, Canada, Permafrost Periglac., 8, 257-277, 1997.

Woo, M.-K. and Young, K. L.: High Arctic wetlands: Their occurrence, hydrological characteristics and sustainability, J.'Hydrol., 320, 432-450, 2006.

Woo, M.-K. and Young, K. L.: Disappearing semi-permanent snow in the High Arctic and its consequences, J. Glaciol., 60, 192-200, 2014.
Young, K. L. and Abnizova, A.: Hydrologic thresholds of ponds in a polar desert wetland environment, Somerset Island, Nunavut, Canada, Wetlands, 31, 535-549, 2011.

Young, K. L. and Labine, C.: Summer hydroclimate of an extensive low-gradient wetland: Polar Bear Pass, Bathurst Island, Nunavut, Canada, Hydrol. Res., 41, 492-502, 2010.

Young, K. L., Woo, M. K., and Edlund, S. A.: Influence of local topography, soils, and vegetation on microclimate and hydrology at a High Arctic site, Ellesmere Island, Canada, Arctic Alpine Res., 29, 270-284, 1997.

Zdanowicz, C., Smetny-Sowa, A., Fischer, D., Schaffer, N., Copland, L., Eley, J., and Dupont, F.: Summer melt rates on Penny Ice Cap, Baffin Island: past and recent trends, and implications for regional climate, J. Geophys. Res., 117, F02006, doi:10.1029/2011JF002248, 2012.

Zhang, X., Harvey, K. D., Hogg, W. D., and Yuzyk, T. R.: Trends in Canadian streamflow, Water Resour. Res., 37, 987-998, 2001. 